\title{
Brood recognition and discrimination in ants
}

\author{
E. Schultner ${ }^{1} \mathbb{D} \cdot$ U. Pulliainen ${ }^{2}$
}

Received: 25 July 2019 / Revised: 3 December 2019 / Accepted: 21 December 2019 / Published online: 22 January 2020 (C) The Author(s) 2020

\begin{abstract}
In social insect colonies, individuals need to communicate to coordinate cooperative tasks and protect the colony and its resources against intruders. To maintain colony integrity, it can be particularly important to recognize nestmates and discriminate against non-nestmate conspecifics and heterospecific predators and parasites. As typical intruders are either con- or heterospecific adults, the mechanisms underlying recognition and discrimination processes in interactions among adults have been well described. Ant brood (eggs, larvae, and pupae) can also play a key role in social interactions, and brood is of special importance when it comes to the priorities of worker ants. However, whether ants can, or even need to, recognize brood of different origins, is not always clear. In this review, we integrate the results of 100 years of study on brood recognition and discrimination in ants into a general framework. We begin with an overview of the proximate mechanisms involved in brood recognition and discrimination. We then discuss why brood recognition and discrimination should evolve and review the evidence for brood recognition on three organizational levels: within nests, between conspecifics and between species. We conclude by examining the constraints acting on accurate recognition and/or discrimination. With this review, we hope to inspire future research on the fascinating life of ant brood.
\end{abstract}

Keywords Social insects $\cdot$ Inclusive fitness $\cdot$ Behavior $\cdot$ Cuticular hydrocarbons $\cdot$ Pheromones $\cdot$ Pupae $\cdot$ Larvae $\cdot$ Eggs

\section{Introduction}

Ants need to assess their social environment and communicate with nestmates to coordinate cooperative processes such as reproductive division of labor, foraging, and brood care. Communication is also crucial for protecting the colony and its resources from exploitation by unrelated conspecific and heterospecific predators and parasites. Mechanisms of taskrelated communication and nestmate and intruder recognition and discrimination have been well reviewed in adult ants (d'Ettorre and Lenoir 2010; van Zweden and d'Ettorre 2010; Sturgis and Gordon 2012; Tsutsui 2013; Czaczkes et al. 2014; Leonhardt et al. 2016), and mainly rely on two kinds of chemical signals: glandular secretions and mixtures of hydrocarbons on the body surface (Vander Meer et al.

\footnotetext{
E. Schultner

eva.schultner@gmail.com

1 Zoology/Evolutionary Biology, Universität Regensburg, Regensburg, Germany

2 Organismal and Evolutionary Biology Research Programme, Faculty of Biological and Environmental Sciences, University of Helsinki, Helsinki, Finland
}

1998; Martin and Drijfhout 2009a; Blomquist and Bagnères 2010; van Wilgenburg et al. 2011). Hydrocarbons are produced in specialized cells (oenocytes) and then transported to the cuticle, where they form a waxy layer that prevents desiccation (Gibbs 1998; Gibbs and Rajpurohit 2010). In many insects, including ants, hydrocarbons have secondarily evolved a function in communication (Blomquist and Bagnères 2010; Chung and Carroll 2015).

Adult ants from the same nest share a hydrocarbon profile, which is partly inherited (Drescher et al. 2010; van Zweden et al. 2010; Nehring et al. 2011; Helanterä and d'Ettorre 2014) and partly shaped by an individual's nutritional and social environment (Soroker et al. 1995; Dahbi et al. 1999; Lenoir et al. 2001a; Foitzik et al. 2007; van Zweden et al. 2009a; Bos et al. 2011). In addition to their species and colony specificity (e.g., Martin et al. 2008a, b), adult hydrocarbon profiles can change with age (Cuvillier-Hot et al. 2001; Teseo et al. 2014), reflect fecundity (Peeters et al. 1999; Liebig et al. 2000; CuvillierHot et al. 2001, 2004; Dietemann et al. 2003, 2005; Holman et al. 2010; Will et al. 2012), and differ among body parts (Wang et al. 2016), task groups (Wagner et al. 1998, 2001; Martin and Drijfhout 2009b; Larsen et al. 2016), 
sexes (Cuvillier-Hot et al. 2001; Kleeberg et al. 2017), and castes (Monnin 1999; Kleeberg et al. 2017). In addition to chemical cues, adult ants can also communicate using acoustic (reviewed in Schönrogge et al. 2017) and visual cues (Hölldobler and Wilson 2009).

Although often overlooked, ant brood (i.e., eggs, larvae, and pupae) play a key role in social interactions (Schultner et al. 2017) and are of special importance when it comes to the decisions and motivation of workers. Ant workers show directed behavior towards brood (Wilson 1971) and retrieving and tending brood is the main priority of a worker ant; even tending to the queen is secondary (Lenoir 1981). This is exemplified by the fact that after disturbance to a colony, the first thing workers do is secure brood (Haskins and Haskins 1950; Lenoir 1981; Muscedere et al. 2009; Römer and Roces 2014). The adaptive advantages of recognizing brood as such are obvious: worker responsiveness to brood is necessary for efficient brood care, which is in the interest of all colony members, because brood represents a colony's combined reproductive investment. As growth and development of ant brood are tightly linked to brood care behavior by workers (Linksvayer 2007, 2008), recognizing and discriminating brood according to traits such as developmental stage, sex, caste, maternity, kinship, colony, population, and species may be selected if it allows colonies to optimize fitnessrelated processes such as the production of sexual offspring.

In this review, we integrate the results of 100 years of study on brood recognition and discrimination in ants into a general framework. The first review on this topic by Carlin (1988) referenced about 30 empirical studies. Since then, 83 studies have examined worker (and sometimes queen or larva) discriminatory behavior towards brood of different developmental stages, sexes, castes, maternities, kinships, colonies, populations, and species. Some of these studies also investigated the underlying cues used for discrimination. We include, to the best of our knowledge, all references published on this topic, irrespective of publication year (see Tables 1, 2, 3 and references therein). We loosely structure our review along the four principles for the study of behavior: causation, ontogeny, adaptive value and phylogeny (Tinbergen 1963). In the section "Brood recognition: how?", we treat the questions of causation and ontogeny by giving an overview of the proximate mechanisms involved in brood recognition and discrimination. In the section "Brood recognition: why?", we discuss the adaptive value of accurate brood recognition and discrimination and review the evidence for discrimination on three organizational levels (within nests, between conspecifics, and between species). We conclude by examining the ecological and experimental constraints that influence accurate recognition and discrimination, or detection thereof. In each section, we present avenues of future research that will help resolve open questions about brood discrimination in ants.

\section{Brood recognition: how?}

Recognition systems typically have three components. The sender produces or bears a stimulus that relates to a relevant trait (expression component). The receiver perceives this stimulus and integrates the information (perception component). The receiver then responds to the sender according to the information gathered from the stimulus (action component). Thus, recognition does not always imply action, but action requires recognition. Recognition is used to describe the neural process associated with assessing the phenotypes of social partners (Waldman 1987), for instance, by reacting to stimuli encoded by genotype or based on context (e.g., shared nest) or prior association. Discrimination is used to describe the differential treatment of social partners following phenotype perception. The majority of studies focus on discrimination, since this is more easily measured than recognition. Here, we use "recognition" when we address the stimuli associated with different phenotypes and "discrimination" when we discuss differential behavior towards individuals of different phenotypes.

Both senders and receivers are critical actors in recognition systems (Fig. 1). In the context of brood recognition and discrimination, brood typically act as senders, while workers act as receivers (although some studies have also tested the recognition and discrimination abilities of queens and larvae, see Tables 1, 2, 3). We begin the first section of this review by examining how brood can transmit information. We then review the current state of knowledge concerning the ontogeny of this behavior in workers.

\section{Brood recognition cues}

Recognition and discrimination are based on the assessment of stimuli in the form of cues or signals. The term "signal" is used for stimuli which have specifically evolved to convey information from sender to receiver, while the term "cue" denotes any stimulus used by the receiver, even if this stimulus did not evolve to function in a communication context (Maynard Smith and Harper 2003). Defining a given stimulus as a signal rather than a cue requires careful testing of the action and function of said stimulus and, in the case of chemical stimuli, a synthetic version, using appropriate behavioral experiments. As such comprehensive studies of brood recognition are rare, we refer to brood recognition stimuli as cues throughout this review, with the exception of queen-borne odors on eggs (i.e., queen pheromones), which have been identified as species-specific signals that have evolved to convey information about queen fertility (Holman et al. 2010; Van Oystaeyen et al. 2014). 
Table 1 Overview of studies conducted on ant brood recognition and discrimination in the context of within-nest interactions

\begin{tabular}{|c|c|c|c|c|c|}
\hline $\begin{array}{l}\text { Discrimination } \\
\text { context }\end{array}$ & Development stage & Species & $\begin{array}{l}\text { Evidence for discrimi- } \\
\text { nation }\end{array}$ & Recognition cues used & References \\
\hline \multirow{11}{*}{$\begin{array}{l}\text { Worker-laid vs. } \\
\text { queen/gamergate- } \\
\text { laid }\end{array}$} & \multirow[t]{11}{*}{ Egg } & $\begin{array}{l}\text { Aphaenogaster } \\
\text { smythiesi japonica }\end{array}$ & Yes & & Iwanishi et al. 2003 \\
\hline & & $\begin{array}{l}\text { Camponutus flori- } \\
\text { danus }\end{array}$ & Yes & Egg odor & Endler et al. 2004 \\
\hline & & $\begin{array}{l}\text { Dinoponera quadri- } \\
\text { ceps }\end{array}$ & Yes & Egg odor & $\begin{array}{l}\text { Monnin and Peeters } \\
1997\end{array}$ \\
\hline & & Formica selysi & Yes & & Meunier et al. 2010 \\
\hline & & $\begin{array}{l}\text { Myrmecia gulosa } \\
\text { (queen) }\end{array}$ & Yes & Egg odor & $\begin{array}{l}\text { Dietemann 2002; Diete- } \\
\text { mann et al. } 2005\end{array}$ \\
\hline & & $\begin{array}{l}\text { Leptothorax acervo- } \\
\text { rum (queen) }\end{array}$ & No & & Bourke 1991 \\
\hline & & $\begin{array}{l}\text { Novomessor cock- } \\
\quad \text { erelli }\end{array}$ & No & & Smith et al. 2008a \\
\hline & & $\begin{array}{l}\text { Temnothorax unifas- } \\
\text { ciatus }\end{array}$ & No & & Stroeymeyt et al. 2007 \\
\hline & & Neoponera inversa & $\begin{array}{l}\text { Depends on queen } \\
\text { presence, brood } \\
\text { origin }\end{array}$ & Egg odor & $\begin{array}{l}\text { d'Ettorre et al. 2004, } \\
\text { 2006; van Zweden } \\
\text { et al. 2007, 2009b }\end{array}$ \\
\hline & & Formica fusca & $\begin{array}{l}\text { Depends on queen } \\
\text { presence }\end{array}$ & & $\begin{array}{l}\text { Helanterä and Sund- } \\
\text { ström 2005, 2007; } \\
\text { Helanterä and Rat- } \\
\text { nieks 2009a }\end{array}$ \\
\hline & & $\begin{array}{l}\text { Diacamma sp. } \\
\text { (gamergate) }\end{array}$ & $\begin{array}{l}\text { Depends on caste of } \\
\text { discriminator }\end{array}$ & Egg odor & $\begin{array}{l}\text { Nakata and Tsuji 1996; } \\
\text { Kikuta and Tsuji } \\
\text { 1999; Shimoji et al. } \\
2012\end{array}$ \\
\hline Queen fertility & Egg & $\begin{array}{l}\text { Camponutus flori- } \\
\text { danus }\end{array}$ & Yes & Egg odor & Endler et al. 2006 \\
\hline \multirow[t]{12}{*}{ Male vs. female } & \multirow[t]{12}{*}{ Egg, larva, pupa } & Formica selysi ${ }^{(?)}$ & Yes & & $\begin{array}{l}\text { Rosset and Chapuisat } \\
2006\end{array}$ \\
\hline & & Lasius niger ${ }^{(\mathrm{L})}$ & Yes & & $\begin{array}{l}\text { Jemielity and Keller } \\
2003\end{array}$ \\
\hline & & Myrmica rubra ${ }^{(\mathrm{L})}$ & Yes & & $\begin{array}{l}\text { Brian and Carr 1960; } \\
\text { Brian } 1981\end{array}$ \\
\hline & & Myrmica tahoensis ${ }^{(\mathrm{L})}$ & Yes & & Evans 1995 \\
\hline & & Pheidole pallidula ${ }^{(?)}$ & Yes & & Keller et al. 1996 \\
\hline & & $\begin{array}{l}\text { Plagiolepis }^{(\mathrm{L})} \\
\text { pygmaea }^{(2)}\end{array}$ & Yes & & Aron et al. 2004 \\
\hline & & Solenopsis invicta ${ }^{(?)}$ & Yes & & Aron et al. 1995 \\
\hline & & $\begin{array}{l}\text { Leptothorax } \\
\text { acervorum }^{(\mathrm{E})}\end{array}$ & No & & Hammond et al. 2002 \\
\hline & & $\begin{array}{l}\text { Camponutus } \\
\text { floridanus }^{(\mathrm{P})}\end{array}$ & $\begin{array}{l}\text { Depends on brood } \\
\text { development stage }\end{array}$ & & $\begin{array}{l}\text { Nonacs and Carlin } \\
1990\end{array}$ \\
\hline & & Formica exsecta $^{(\mathrm{L})}$ & $\begin{array}{l}\text { Depends on queen } \\
\text { number }\end{array}$ & & Sundström et al. 1996 \\
\hline & & Linepithema humile ${ }^{(\mathrm{L})}$ & $\begin{array}{l}\text { Depends on queen } \\
\text { presence, brood } \\
\text { development stage }\end{array}$ & & $\begin{array}{c}\text { Aron et al. 1994; Pas- } \\
\text { sera et al. 1995; Pas- } \\
\text { sera and Aron } 1996\end{array}$ \\
\hline & & $\begin{array}{l}\text { Monomorium } \\
\text { pharaonis }^{(\mathrm{L})}\end{array}$ & $\begin{array}{l}\text { Depends on brood } \\
\text { development stage }\end{array}$ & & $\begin{array}{l}\text { Peacock et al. 1954; } \\
\text { Warner et al. } 2016\end{array}$ \\
\hline
\end{tabular}


Table 1 (continued)

\begin{tabular}{|c|c|c|c|c|c|}
\hline $\begin{array}{l}\text { Discrimination } \\
\text { context }\end{array}$ & Development stage & Species & $\begin{array}{l}\text { Evidence for discrimi- } \\
\text { nation }\end{array}$ & Recognition cues used & References \\
\hline \multirow[t]{5}{*}{ Trophic vs. viable } & \multirow[t]{5}{*}{ Egg } & Lasius niger (larva) & Yes & & Baroni Urbani 1991 \\
\hline & & $\begin{array}{l}\text { Novomessor cock- } \\
\text { erelli }\end{array}$ & Yes & & $\begin{array}{l}\text { Hölldobler and Carlin } \\
1989\end{array}$ \\
\hline & & Rhytidoponera sp.12 & Yes & & Tay and Crozier 2000 \\
\hline & & $\begin{array}{l}\text { Messor semirufus } \\
\quad \text { (larva) }\end{array}$ & No & & Baroni Urbani 1991 \\
\hline & & Myrmecia gulosa & $\begin{array}{l}\text { Depends on worker } \\
\text { size }\end{array}$ & Egg odor & $\begin{array}{l}\text { Dietemann 2002; Diete- } \\
\text { mann et al. } 2005\end{array}$ \\
\hline \multirow[t]{6}{*}{$\begin{array}{l}\text { Worker-destined vs. } \\
\text { queen-destined }\end{array}$} & \multirow[t]{6}{*}{ Larva, pupa } & $\begin{array}{l}\text { Harpegnathos } \\
\text { saltator }\end{array}$ & Yes & Larva odor & Penick and Liebig 2017 \\
\hline & & $\begin{array}{l}\text { Aphaenogaster } \\
\text { senilis }^{(\mathrm{L})}\end{array}$ & $\begin{array}{l}\text { Depends on queen } \\
\text { presence }\end{array}$ & & Villalta et al. 2016 \\
\hline & & Linepithema humile $^{(\mathrm{L})}$ & $\begin{array}{l}\text { Depends on queen } \\
\text { presence }\end{array}$ & & $\begin{array}{l}\text { Passera et al. 1995; } \\
\text { Klobuchar and } \\
\text { Deslippe } 2002\end{array}$ \\
\hline & & $\begin{array}{l}\text { Monomorium }^{(\mathrm{L})} \\
\text { pharaonis }^{(}\end{array}$ & $\begin{array}{l}\text { Depends on queen } \\
\text { presence, brood } \\
\text { development stage }\end{array}$ & Larval pilosity & $\begin{array}{l}\text { Edwards 1991; Warner } \\
\text { et al. } 2016\end{array}$ \\
\hline & & Myrmica rubra ${ }^{(\mathrm{L}, \mathrm{P})}$ & $\begin{array}{l}\text { Depends on queen } \\
\text { presence }\end{array}$ & Larval secretions & Brian 1973c, b, 1975a \\
\hline & & Solenopsis invicta ${ }^{(\mathrm{L})}$ & $\begin{array}{l}\text { Depends on queen } \\
\text { presence, brood } \\
\text { development stage }\end{array}$ & & $\begin{array}{l}\text { Glancey et al. 1970; } \\
\text { Vargo and Fletcher } \\
\text { 1986; Klobuchar and } \\
\text { Deslippe } 2002\end{array}$ \\
\hline \multirow[t]{10}{*}{ Size, age } & Young vs. old larva & $\begin{array}{l}\text { Monomorium } \\
\text { pharaonis }\end{array}$ & Yes & & Walsh et al. 2018b \\
\hline & $\begin{array}{l}\text { Larva vs. pupa; small } \\
\text { larva vs. large larva, } \\
\text { egg vs. larva }\end{array}$ & Lasius niger & Yes & & Lenoir 1981 \\
\hline & $\begin{array}{l}4^{\text {th }} \text { instar larva vs. } \\
\text { other larval instars }\end{array}$ & Solenopsis invicta & Yes & & $\begin{array}{l}\text { Petralia and Vinson } \\
1979 \mathrm{~b}\end{array}$ \\
\hline & \multirow[t]{6}{*}{ Larva vs. pupa } & $\begin{array}{l}\text { Acromyrmex echina- } \\
\text { tor }\end{array}$ & Yes & & Fouks et al. 2011 \\
\hline & & Myrmica rubra & Yes & & Brian 1975a \\
\hline & & Myrmica sabuleti & Yes & & Thomas et al. 2013 \\
\hline & & Myrmica scabrinodis & Yes & & Casacci et al. 2013 \\
\hline & & Myrmica schenki & Yes & & Thomas et al. 1998 \\
\hline & & Solenopsis invicta & Yes & Larva odor, pupa odor & Glancey et al. 1970 \\
\hline & $\begin{array}{l}\text { Larva vs. pupa, small } \\
\text { vs. large larva }\end{array}$ & Linepithema humile & $\begin{array}{l}\text { Depends on queen } \\
\text { presence }\end{array}$ & & Passera et al. 1995 \\
\hline
\end{tabular}

Discrimination abilities of workers were tested unless otherwise noted in parentheses behind the species name. For discrimination contexts in which more than one development stage was tested, details on the tested stage are given in superscript behind the species name ( $E$ egg, $L$ larva, $P$ pupa, ? unknown). Where available, information on the cues used for recognition is given

Wheeler $(1910,1918)$ first proposed that ant larvae emit chemical attractants. Worker attraction towards conspecific brood odors was then demonstrated in the army ants Neivamyrmex opacithorax and Eciton spp. (Watkins and Cole 1966; Schneirla 1971) and shortly after confirmed in Atta cephalotes (Robinson and Cherrett 1974), Myrmica rubra (Brian 1975a), and Solenopsis invicta (Glancey et al.
1970, but see Walsh and Tschinkel 1974). These findings, together with the fact that ant workers are known to readily accept and rear conspecific non-nestmate brood (Table 2) inspired researchers to search for ant brood pheromones, i.e., chemical substances emitted by immature individuals that elicit a specific response in conspecific adults (Morel and Vander Meer 1988; Vander Meer and Alonso 1998). 
Table 2 Overview of studies conducted on ant brood recognition and discrimination in the context of conspecific interactions

Discrimination context Development stage Species $\quad$ Evidence for discrimi- Recognition cues used References
nation

\begin{tabular}{|c|c|c|c|c|c|}
\hline \multirow[t]{26}{*}{$\begin{array}{l}\text { Nestmate vs. non- } \\
\text { nestmate }\end{array}$} & Egg, larva, pupa & $\begin{array}{l}\text { Acromyrmex } \\
\quad \text { subterraneus } \\
\text { subterraneus }^{(\mathrm{L}, \mathrm{P})}\end{array}$ & Yes & Pupa odor & Viana et al. 2001 \\
\hline & & $\begin{array}{l}\text { Atta sexdens } \\
\quad \text { rubropilosa }^{(\mathrm{E}, \mathrm{L}, \mathrm{P})}\end{array}$ & Yes & & Araujo et al. 1996 \\
\hline & & $\begin{array}{l}\text { Leptothorax acervo- } \\
\text { rum (queen) })^{(\mathrm{E})}\end{array}$ & Yes & & Bourke 1994 \\
\hline & & $\begin{array}{l}\text { Leptothorax } \\
\quad \text { longispinosus }^{(\mathrm{L})}\end{array}$ & Yes & Larva odor & $\begin{array}{l}\text { Hare 1996; Swan and } \\
\text { Hare } 2012\end{array}$ \\
\hline & & Myrmica schencki $i^{(\mathrm{L})}$ & Yes & Larva odor & Akino et al. 1999 \\
\hline & & $\begin{array}{r}\text { Temnothorax } \\
\text { nylanderi }^{(\mathrm{L})}\end{array}$ & Yes & & Swan and Hare 2012 \\
\hline & & $\begin{array}{r}\text { Temnothorax } \\
\text { parvulus }^{(\mathrm{L})}\end{array}$ & Yes & & Swan and Hare 2012 \\
\hline & & $\begin{array}{l}\text { Acromyrmex laticeps } \\
\text { nigrosetosus }^{(\mathrm{L}, \mathrm{P})}\end{array}$ & No & & Souza et al. 2006 \\
\hline & & $\begin{array}{l}\text { Formica aquilonia } \\
{\text { (larva })^{(\mathrm{E})}}\end{array}$ & No & & Schultner et al. 2013 \\
\hline & & Formica gnava ${ }^{(\mathrm{P})}$ & No & & $\begin{array}{l}\text { Goodloe and Topoff } \\
1987\end{array}$ \\
\hline & & $\begin{array}{l}\text { Formica } \\
\quad \text { paralugubris }^{(\mathrm{P})}\end{array}$ & No & & Maeder et al. 2005 \\
\hline & & Formica pratensis ${ }^{(\mathrm{P})}$ & No & & $\begin{array}{l}\text { Rosengren and Cherix } \\
1981\end{array}$ \\
\hline & & Formica sanguinea $^{(\mathrm{P})}$ & No & & Mori et al. 1992 \\
\hline & & Formica schaufussi $i^{(\mathrm{P})}$ & No & & $\begin{array}{l}\text { Goodloe and Topoff } \\
1987\end{array}$ \\
\hline & & $\begin{array}{l}\text { Messor semirufus } \\
\quad(\text { larva })^{(\mathrm{E})}\end{array}$ & No & & Baroni Urbani 1991 \\
\hline & & Myrmecia sp. ${ }^{(\mathrm{E}, \mathrm{L}, \mathrm{P})}$ & No & & $\begin{array}{l}\text { Haskins and Haskins } \\
1950\end{array}$ \\
\hline & & $\begin{array}{l}\text { Oecophylla } \\
\quad \text { smaragdina }\end{array}$ & No & & Krag et al. 2010 \\
\hline & & $\begin{array}{l}\text { Rhytidoponera } \\
\text { confusa }^{(\mathrm{L})}\end{array}$ & No & & Crosland 1988 \\
\hline & & Promyrmecia sp. ${ }^{(\mathrm{E}, \mathrm{L}, \mathrm{P})}$ & No & & $\begin{array}{l}\text { Haskins and Haskins } \\
1950\end{array}$ \\
\hline & & Tapinoma erraticum ${ }^{(\mathrm{P})}$ & No & & Meudec 1978 \\
\hline & & $\begin{array}{l}\text { Acromyrmex } \\
\text { echinator }^{(\mathrm{L}, \mathrm{P})}\end{array}$ & $\begin{array}{l}\text { Depends on worker } \\
\text { caste }\end{array}$ & & $\begin{array}{l}\text { Fouks et al. 2011; } \\
\text { Larsen et al. } 2014\end{array}$ \\
\hline & & Atta cephalotes $^{(\mathrm{L}, \mathrm{P})}$ & $\begin{array}{l}\text { Depends on brood } \\
\text { development stage }\end{array}$ & & $\begin{array}{l}\text { Robinson and Cherrett } \\
1974\end{array}$ \\
\hline & & $\begin{array}{l}\text { Camponotus }^{(\mathrm{P})} \\
\text { floridanus }^{(\mathrm{P})}\end{array}$ & Depends on brood sex & & $\begin{array}{l}\text { Carlin and Schwartz } \\
\text { 1989; Nonacs and } \\
\text { Carlin } 1990\end{array}$ \\
\hline & & Cataglyphis cursor ${ }^{(\mathrm{L})}$ & $\begin{array}{l}\text { Depends on worker } \\
\text { pre-eclosion experi- } \\
\text { ence }\end{array}$ & & $\begin{array}{l}\text { Lenoir 1984; Isingrini } \\
\text { et al. 1985; Isingrini } \\
\text { 1987; Isingrini and } \\
\text { Lenoir } 1988\end{array}$ \\
\hline & & $\begin{array}{l}\text { Dinoponera } \\
\quad \text { quadriceps }\end{array}$ & $\begin{array}{l}\text { Depends on worker } \\
\text { age }\end{array}$ & & $\begin{array}{l}\text { Tannure-Nascimento } \\
\text { et al. } 2009\end{array}$ \\
\hline & & $\begin{array}{l}\text { Ectatomma } \\
\quad \text { tuberculatum }^{(\mathrm{L})}\end{array}$ & $\begin{array}{l}\text { Depends on worker } \\
\text { age }\end{array}$ & & $\begin{array}{l}\text { Fénéron and Jaisson } \\
1995\end{array}$ \\
\hline
\end{tabular}


Table 2 (continued)

\begin{tabular}{|c|c|c|c|c|c|}
\hline Discrimination context & Development stage & Species & $\begin{array}{l}\text { Evidence for discrimi- } \\
\text { nation }\end{array}$ & Recognition cues used & References \\
\hline & & $\begin{array}{l}\text { Formica fusca } \\
\quad(+ \text { larva })^{(\mathrm{E}, \mathrm{P})}\end{array}$ & $\begin{array}{l}\text { Depends on queen } \\
\text { presence, worker } \\
\text { post-eclosion experi- } \\
\text { ence }\end{array}$ & & $\begin{array}{l}\text { Jaisson 1975; Helanterä } \\
\text { and Sundström 2007; } \\
\text { Helanterä et al. 2007, } \\
\text { 2014; Helanterä and } \\
\text { Ratnieks 2009a; Pul- } \\
\text { liainen et al. } 2019\end{array}$ \\
\hline & & Formica exsecta $^{(\mathrm{P})}$ & $\begin{array}{l}\text { Depends on brood } \\
\text { caste }\end{array}$ & & Pulliainen et al. 2018 \\
\hline & & Formica lugubris $^{(\mathrm{P})}$ & $\begin{array}{l}\text { Depends on brood } \\
\text { origin }\end{array}$ & & $\begin{array}{l}\text { Rosengren and Cherix } \\
\text { 1981; Rosengren et al. } \\
\text { 1994; Maeder et al. } \\
\text { 2005 }\end{array}$ \\
\hline & & Formica rufa ${ }^{(\mathrm{P})}$ & $\begin{array}{l}\text { Depends on worker } \\
\text { post-eclosion experi- } \\
\text { ence, brood origin }\end{array}$ & & $\begin{array}{l}\text { Le Moli and Passetti } \\
\text { 1977, 1978; Rosen- } \\
\text { gren and Cherix } 1981\end{array}$ \\
\hline & & Formica selysi $^{(\mathrm{E})}$ & $\begin{array}{l}\text { Depends on worker } \\
\text { origin }\end{array}$ & & Meunier et al. 2010 \\
\hline & & $\begin{array}{l}\text { Lasius niger } \\
\quad(\text { larva })^{(\mathrm{E}, \mathrm{L}, \mathrm{P})}\end{array}$ & $\begin{array}{l}\text { Depends on identity of } \\
\text { discriminator }\end{array}$ & & $\begin{array}{l}\text { Lenoir 1981; Baroni } \\
\text { Urbani } 1991\end{array}$ \\
\hline & & Myrmica rubra $^{(\mathrm{L})}$ & $\begin{array}{l}\text { Depends on experi- } \\
\text { mental setup }\end{array}$ & & $\begin{array}{l}\text { Elmes and Wardlaw } \\
\text { 1983; Solazzo et al. } \\
2013\end{array}$ \\
\hline & & $\begin{array}{l}\text { Temnothorax } \\
\text { ambiguus }^{(\mathrm{L})}\end{array}$ & $\begin{array}{l}\text { Depends on brood } \\
\text { origin }\end{array}$ & & Swan and Hare 2012 \\
\hline & & $\begin{array}{l}\text { Temnothorax } \\
\text { unifasciatus }^{(\mathrm{P})}\end{array}$ & $\begin{array}{l}\text { Depends on enslave- } \\
\text { ment status of colony }\end{array}$ & & Delattre et al. 2012 \\
\hline $\begin{array}{l}\text { Monogyne colony vs. } \\
\text { polygyne colony }\end{array}$ & Egg & Formica selysi & Yes & Egg odor & Meunier et al. 2011 \\
\hline
\end{tabular}

Discrimination abilities of workers were tested unless otherwise noted in parentheses behind the species name. For discrimination contexts in which more than one development stage was tested, details on the tested stage are given in superscript behind the species name ( $E$ egg, $L$ larva, $P$ pupa, ? unknown). Where available, information on the cues used for recognition is given

Such brood pheromones exist in the honey bee Apis mellifera (Le Conte et al. 1990), where they are produced in larval salivary glands (Le Conte et al. 2006) and have a distinct role in modulating worker behavior and physiology (Mohammedi et al. 1996; Le Conte et al. 2001).

A first attempt at characterizing ant brood pheromones was conducted by Bigley and Vinson (1975), who identified the pupal pheromone of Solenopsis invicta as triolein. Similarly, Glancey and Dickens (1988) claimed to have isolated a larval brood pheromone from the same species. However, these identifications were later claimed to be inaccurate (Vander Meer 1983), and the overall existence of ant brood pheromones argued against, with particular focus on the unreliability of the performed assays and the lack of species specificity in the action of the identified compounds (Morel and Vander Meer 1988; Vander Meer and Morel 1988; Vander Meer and Alonso 1998). Indeed, interspecific brood adoption by worker ants has been widely reported (Table 3), lending support to the notion that ant brood pheromones-by definition, substances that elicit reactions from conspecifics-do not exist. Careful work on brood odors in the fire ant $S$. invicta (reviewed in Tschinkel 2006), as well as recent studies on a number of different species spanning the ant phylogeny have demonstrated that the presence of brood influences adult behavior and reproductive physiology (Heinze et al. 1996; Endler et al. 2004; Teseo et al. 2013; Ebie et al. 2015; Ulrich et al. 2016; Chandra et al. 2018), and that this inhibition can be caused by larval contact odors alone (Villalta et al. 2015). While these results seemingly provide support for the idea that ant brood pheromones exist, studies testing whether such brood odors act in a species-specific manner are still lacking. One can hope that a species-comparative approach using modern methods of chemical analysis and carefully designed bioassays will help elucidate the chemical nature of these compounds in the future.

Beyond this burst of interest in brood pheromones, individual brood items, in particular larvae, were often regarded 


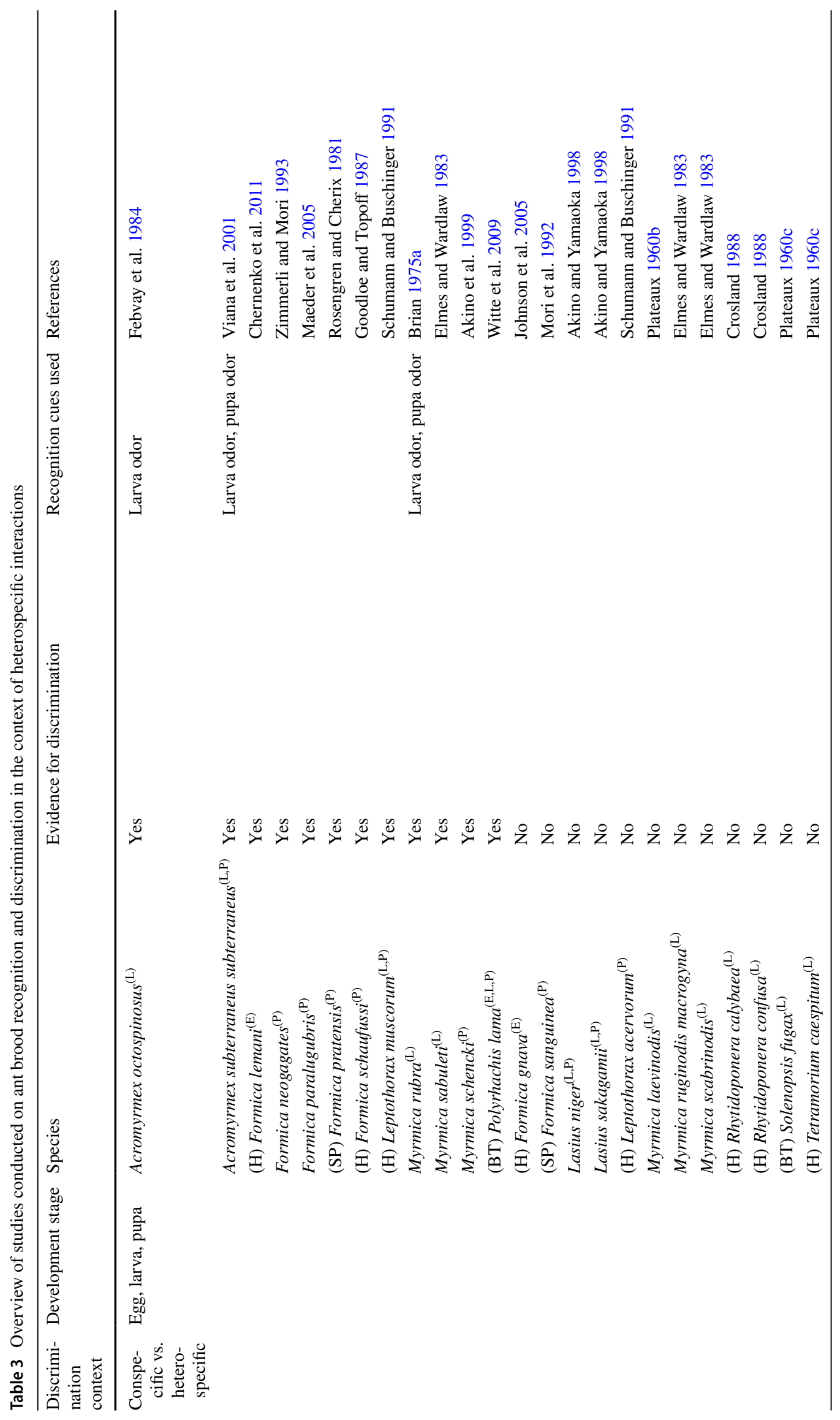




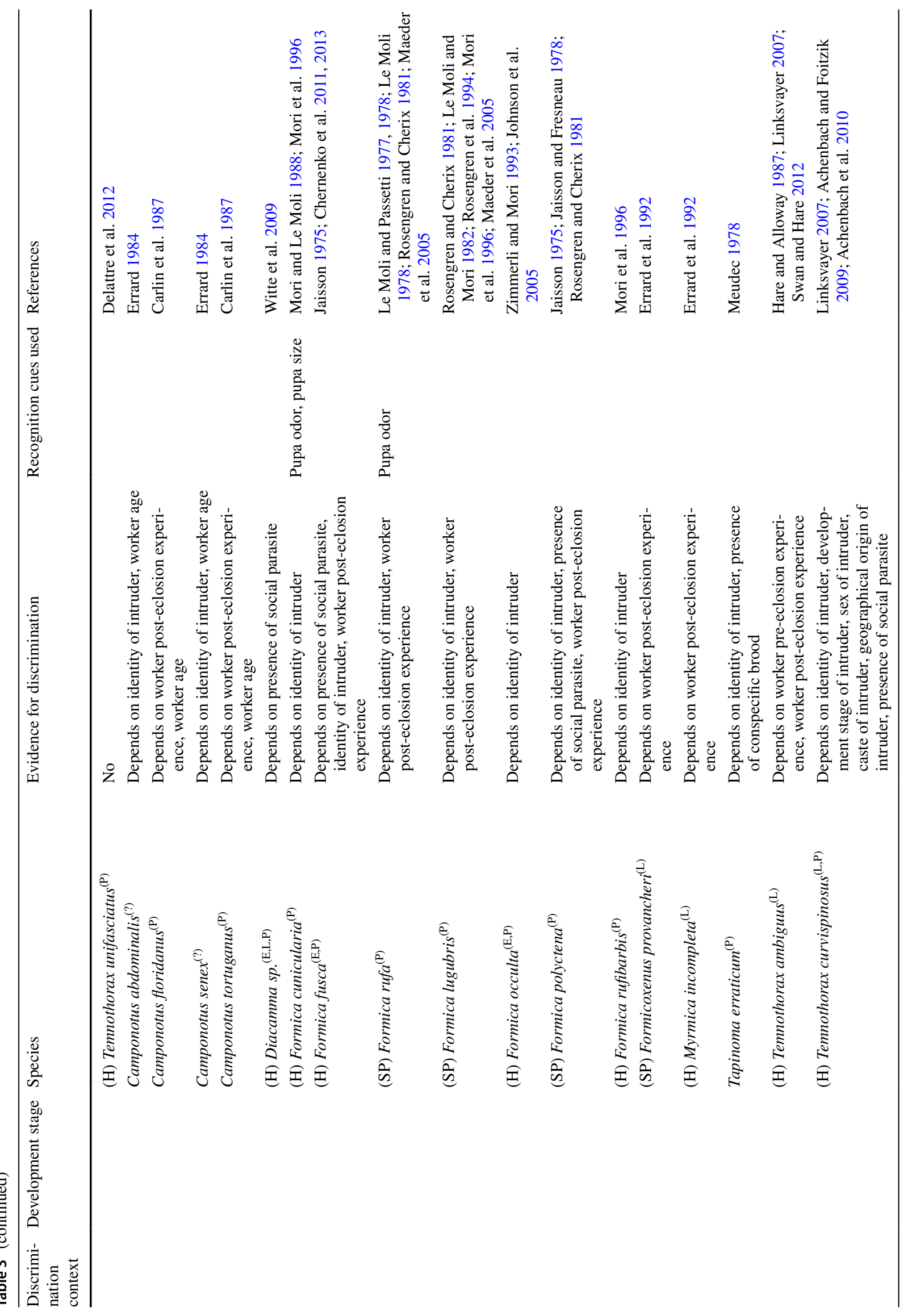


as chemically insignificant. Brood hydrocarbon profiles have indeed been shown to be less complex than adult cuticular profiles in some species (Viana et al. 2001; Richard et al. 2007; Fouks et al. 2011). However, the complexity of egg, larval and pupal profiles can also mirror that of adult profiles (Bagnères and Morgan 1991; Akino et al. 1999; Elmes et al. 2002; Souza et al. 2006; Tannure-Nascimento et al. 2009; Helanterä and d'Ettorre 2014). We now know that brood surface chemistry can be species, population, and colonyspecific (Brian 1975a; Le Moli and Passetti 1978; Mori and Le Moli 1988; Hare 1996; Akino et al. 1999; Viana et al. 2001; Johnson et al. 2005; Souza et al. 2006; Richard et al. 2007; Achenbach and Foitzik 2009; Achenbach et al. 2010; Schultner et al. 2013; Helanterä and d'Ettorre 2014; Pulliainen et al. 2018, Peignier et al. 2019), and contain information about traits like viability (Dietemann et al. 2005), maternity (Monnin and Peeters 1997; Endler et al. 2004, 2006; d'Ettorre et al. 2004, 2006; Dietemann et al. 2005; Meunier et al. 2010; Shimoji et al. 2012; Helanterä and d'Ettorre 2014), development stage (Johnson et al. 2005; Richard et al. 2007), sex (Achenbach et al. 2010), caste (Brian 1975a; Achenbach et al. 2010; Penick and Liebig 2017), and colony social structure (Meunier et al. 2011).

Brood recognition can also be based on non-chemical cues such as morphology, behavior, and acoustic signals. Ant larvae show striking diversity in body size and shape, overall mobility, and morphology of body hairs (Wheeler 1918; Wheeler and Wheeler 1953, 1976, 1986). In particular the size, shape, distribution and density (= pilosity) of larval hairs can differ between species, as well as between developmental stages, sexes and castes within single species (Petralia and Vinson 1978, 1979a; Solis et al. 2010b, a, 2011, 2012b, a; Fox et al. 2011; Penick et al. 2012; Wang et al. 2017). In Monomorium and Solenopsis ants, differences in the pilosity of worker- and queen-destined larvae may help workers recognize the two castes (Edwards 1991; Fox et al. 2011). In Myrmica ants, the increasing pilosity of larvae over the course of development has been suggested to be crucial for recognition, together with brood chemistry and tactile cues such as turgidity, size, shape, and cuticle surface properties (Brian 1975a). Formica cunicularia workers also seem to use a combination of cues to recognize brood as only heterospecific brood that resembles conspecific brood in both size and odor are accepted (Mori and Le Moli 1988). Larval behavior can also transmit information to workers, for instance in the context of nutritional provisioning. This is exemplified by the correlation between larval head movements and worker feeding behavior in Myrmica rubra (Creemers et al. 2003). The pupae of the closely related species Myrmica scabrinodis communicate acoustically with workers using stridulatory organs (Casacci et al. 2013). Judging from the sheer diversity of ant brood morphology, there are many more such fascinating traits to be discovered. 
Fig. 1 Overview of factors influencing brood recognition and discrimination in ants
Presence of conspecific brood

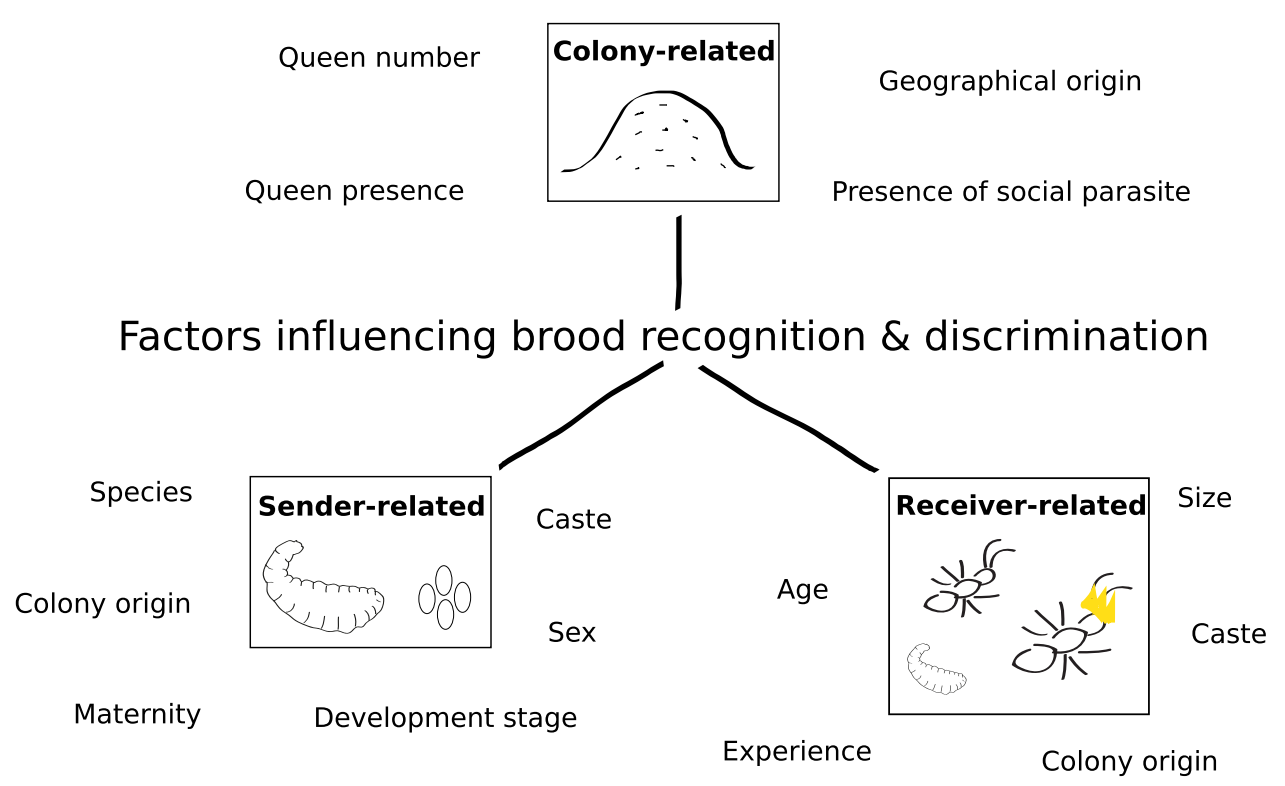

\section{Ontogeny of brood recognition and discrimination behavior}

Ant workers develop from female eggs, which hatch into larvae that pass through 3-5 instars (depending on the species) and a short pre-pupal phase, before undergoing complete metamorphosis and remaining in a pupal stage until eclosing as adults. Adult ants detect chemical compounds with a chemosensory system, including a range of proteins in the antennal sensilla that detect, bind and carry odorant molecules (Ozaki et al. 2005; Kulmuni and Havukainen 2013; McKenzie et al. 2014; Pask et al. 2017; Slone et al. 2017; McKenzie and Kronauer 2018). The olfactory stimuli are then perceived in the antennal lobes and the higher integration centres in the brain, and ultimately lead to behavioral responses (Ozaki and Wada-Katsumata 2010; Trible et al. 2017; Yan et al. 2017). Social interactions play a key role in modulating neurophysiological processes, and lack thereof can inhibit growth and development of important learning and memory centers in the brain, in addition to other negative neurochemical effects (Boulay et al. 2000; Wada-Katsumata et al. 2011; Seid and Junge 2016).

Although the neurophysiology of brood recognition has not been studied, current data suggest that odor-based recognition abilities of worker ants are shaped by the integration of multiple chemical templates during both larval and adult life. For example, Cataglyphis cursor workers are able to discriminate larvae according to colony origin within $24 \mathrm{~h}$ of eclosion (Isingrini and Lenoir 1988), indicating that preimaginal learning shapes recognition abilities (Isingrini et al. 1985). Similarly, pre-imaginal learning appears to affect recognition abilities in Camponotus spp., Aphaenogaster senilis and Leptothorax spp. workers (Hare and Alloway 1987; Carlin and Schwartz 1989; Signorotti et al. 2014). While this suggests that this phenomenon is universal in ants, there are also examples, where pre-eclosion experience does not affect discriminatory behavior, e.g., in Temnothorax parvulus (Blatrix and Sermage 2005).

After eclosing as adults, young workers typically act as nurses within the nest, before transitioning to become foragers when they are older (but see Muscedere et al. 2009). This age-based division of labor can be reflected in both recognition abilities and discriminatory behavior. In Ectatomma tubercalutum, only $2-10$ week old workers (the age that corresponds to the nursing period in this species) discriminate between nestmate and non-nestmate larvae and pupae, whereas older workers lose the preference for nestmate brood (Fénéron and Jaisson 1992, 1995). Similarly, in Dinoponera quadriceps only 1-6 week old workers (i.e., nurses) were able to discriminate between nestmate and non-nestmate eggs, whereas younger (callows) or older (foragers) workers were not (Tannure-Nascimento et al. 2009). The change in recognition capacity seems to be related to the current task of the worker, rather than to age per se (Fénéron and Jaisson 1992), and the loss of preference for nestmate eggs in foragers might result from a lack of continuous updating of the chemical template (Fénéron and Jaisson 1995). This is supported by studies showing that workers adopt unfamiliar brood more readily if they do not have access to a chemical template of familiar brood or if they have been previously exposed to unfamiliar con- or heterospecific brood (Jaisson 1975; Le Moli and Passetti 1977; Jaisson and Fresneau 1978; Le Moli and Passetti 1978; Lenoir 1981; Le Moli and Mori 1982; Isingrini et al. 1985; Carlin et al. 1987; Hare and 
Alloway 1987; Helanterä et al. 2007; Helanterä and Ratnieks 2009a; Swan and Hare 2012). For example, F. fusca workers taken from a colony enslaved by Formica sanguinea accept foreign brood, while workers taken from unparasitized nests do not (Jaisson 1975).

Some ant species have morphological worker castes that are specialized for discrete tasks; such morphological specialization may also influence recognition and discrimination abilities. In Acromyrmex echinator, different morphological castes differ in their aggression towards conspecifics (Larsen et al. 2014). Compared to minor workers, major workers are more aggressive towards adult conspecifics and discriminate against non-nestmate brood. This is thought to be the result of lower sensitivity to nestmate odors in minor workers, which usually do not defend the nest against intruders. Even in species without morphological worker castes, workers can vary in size, and this may affect task partitioning and consequently, brood-discrimination behavior. In colonies of Myrmecia gulosa ants, small workers kill viable eggs while large workers do not (Dietemann 2002). Whether this is due to differences in recognition abilities or experience, or because large workers simply refrain from egg killing, is not known.

Overall, although recognition mechanisms in ants have not been studied exhaustively, it is known that they are highly flexible, context-dependent and modulated by dynamic thresholds and integration of multiple templates (Gamboa et al. 1991; van Zweden and d'Ettorre 2010; Newey 2011; Sturgis and Gordon 2012). While we are beginning to understand how adult ants perceive social information (Ozaki et al. 2005; Brandstaetter et al. 2011; Pask et al. 2017; Trible et al. 2017; Yan et al. 2017; Neupert et al. 2018), comparative analyses across species and genera are needed to draw general conclusions about the ability of workers to recognize brood, and how such abilities may be ontogenetically constrained.

\section{Brood recognition: why?}

Given that brood from conspecific and even heterospecific nests are often readily accepted (Tables 2,3 ), it may appear as if brood discrimination has no selective advantage. Indeed, as the immature stages of ants are largely immobile, they are not potential intruders of colonies. Compared to discrimination of adult individuals, the ability to recognize and discriminate brood may thus be under less stringent selection, and general cues identifying brood as brood may override more specific information on individual traits (Carlin 1988). Nonetheless, there are several scenarios in which precise brood recognition and discrimination are predicted to evolve. First, the identity of brood (e.g., developmental stage, sex, caste, maternity) can be a key modulator of within-colony interactions, particularly in the case of colony-level conflicts over resource allocation (Schultner et al. 2017). Second, recognition of, and discrimination against, foreign brood may be crucial in maintaining colony integrity, especially in species which are targeted by social parasites that exploit the brood care behavior of the host (Schmid-Hempel 1995). In the second section of this review, we discuss the adaptive value of accurate brood recognition and discrimination and review the evidence for discrimination on three organizational levels (within nests, between conspecifics, and between species) across the ant phylogeny.

\section{Within-nest interactions}

Within ant nests, the needs of brood play a major role in dictating the behavior and physiology of adult nestmates (Schultner et al. 2017). For example, since ant brood are not restricted to individual cells but instead reared in piles, nurse workers continually adjust the location of brood within nests to ensure optimal microclimatic conditions for growth and development (Brian 1973a; Hölldobler and Wilson 1990; Penick and Tschinkel 2008; Römer and Roces 2014). As the needs of brood can vary depending on traits like developmental stage, sex and caste, workers are under selection to recognize brood precisely to adjust rearing conditions on an individual basis. Some ants are known to sort brood according to developmental stage or size (Le Masne 1953; Sendova-Franks et al. 2004), which can help increase efficiency of brood care (Franks and Sendova-Franks 1992) and prevent within-brood cannibalism (Rüger et al. 2007). From an inclusive fitness-centered point of view, discriminating developing individuals according to traits like maternity, sex, and caste can play a key role in within-colony conflicts over reproductive dominance, sex allocation and caste allocation (Schultner et al. 2017).

\section{Feeding interactions}

A colony's feeding interactions are centered around larvae, which are both the major consumers of worker provisions and providers of the fundamental service of protein processing to the colony (Hölldobler and Wilson 1990). Access to information about brood traits such as developmental stage, size, sex, maternity, caste and hunger level can help workers optimize their feeding behavior, for example in cases, where brood of different ages, sexes, or castes have different nutritional requirements (Brian 1981; Boomsma and Isaaks 1985; Cassill and Tschinkel 1996; Smith et al. 2008b; Smith and Suarez 2010). Recognizing hungry larvae can help workers optimally allocate food (Brian and Abbott 1977; Cassill and Tschinkel 1999; Lopes et al. 2005) and both behavioral and chemical cues have been implicated in larval begging (Le Masne 1953; Vowles 1955; Cassill and Tschinkel 
1995; Creemers et al. 2003; Kaptein et al. 2005; Pegnier et al. 2019). Importantly, since it is commonly assumed that queen-worker caste differentiation is modulated by differences in individual nutritional provisioning, workers should be able to adjust their feeding behavior according to larval caste to produce the polymodal size distribution of female castes observed in many species (Trible and Kronauer 2017).

Information about brood traits may also be useful in the context of brood cannibalism, i.e., when adult colony members consume brood, feed brood to larvae during periods of resource shortage (Crespi 1992), or when larvae selfishly consume other brood (Baroni Urbani 1991; Rüger et al. 2007; Schultner et al. 2013, 2014). According to inclusive fitness theory, least related brood should be consumed first, along with early brood stages that have not yet consumed large amounts of colony resources (Elgar and Crespi 1992). Prerequisites for such discriminatory behavior are the ability to assess the relatedness or developmental stage of brood. This appears to be the case in Formica wood ants, in which larvae preferentially cannibalize unrelated eggs (Schultner et al. 2013, 2014). Furthermore, it may be important to discriminate between viable and unviable eggs, particularly in species that produce trophic eggs that are meant to be consumed (e.g., Dietemann and Peeters 2000). This is the case in Myrmecia gulosa, where workers destroy unviable but not viable worker-laid eggs (Dietemann et al. 2005). In the ant Lasius niger, larvae discriminate between viable and trophic eggs and consume the latter preferentially (Baroni Urbani 1991). In contrast, Leptothorax acervorum queens do not discriminate between viable and trophic eggs and consume both at similar rates (Bourke 1991).

\section{Maternity and kinship}

In many species, workers are able to lay unfertilized, maledestined eggs (Hölldobler and Wilson 1990; Bourke and Franks 1995a). Worker reproduction decreases colony productivity and efficiency (e.g., Hartmann et al. 2003). As a result, reproducing workers are often punished by nestmate queens or workers, either via direct aggression or destruction of worker-laid eggs (policing: Ratnieks 1988). This is most likely mediated by queen-borne fertility signals on the egg surface (Holman et al. 2010), which appear to be conserved across social Hymenoptera (Van Oystaeyen et al. 2014). Indeed, discrimination between queen and worker-laid eggs has been demonstrated in a number of species and is often linked to differences in the odor profiles of eggs (Table 1). In the carpenter ant Camponotus floridanus, chemical cues can even distinguish eggs laid by highly fertile queens from those laid by queens of low fertility (Endler et al. 2006). Whether workers act on the information provided by egg odor profiles can depend on the presence of the queen
(d'Ettorre et al. 2004; Helanterä and Sundström 2007) and colony origin (van Zweden et al. 2009b).

In colonies with more than one reproductive individual (i.e., multiple queen colonies, colonies with totipotent workers), brood cues can help signal reproductive dominance. For example, in queenless Dinoponera and Diacamma ants, societies consist of morphologically similar, totipotent individuals that can produce both male and female eggs. Here, reproductive dominance is established via behavioral interactions, and eggs laid by subordinate individuals are preferentially destroyed; this behavior is most likely mediated by differences in the proportions of certain hydrocarbons on the egg surface (Monnin and Peeters 1997; Shimoji et al. 2012).

Finally, in colonies that contain more than one reproducing queen, workers can increase their inclusive fitness by selectively directing their altruistic actions towards their closest relatives (so-called nepotism). Overall, nepotism in social insects is rare (Boomsma and d'Ettorre 2013), but Hannonen and Sundström (2003) found that Formica fusca workers were able to assess the kinship of eggs in their care and act on this information by favouring eggs of a more closely related queen. Holzer et al. (2006) attempted to confirm these results by presenting Formica exsecta workers with a choice between sisters and unrelated eggs but failed to find signs of nepotism. Instead, they concluded that the distinctive pattern of brood composition was caused by differential egg viability, casting doubt on the earlier study. Nevertheless, a study on egg signature mixtures in Formica ants showed that egg chemical profiles are highly variable and potentially provide sufficient information for discrimination between matrilines within nests (Helanterä and d'Ettorre 2014). Whether or not this information is used likely depends on species-specific biology: in contrast to F. exsecta, F. fusca is a common host to ant social parasites and displays excellent discrimination abilities (Helanterä and Sundström 2007; Helanterä and Ratnieks 2009a; Chernenko et al. 2011, 2013; Helanterä et al. 2011; Martin et al. 2011; Pulliainen et al. 2019). Contrasting patterns of brood discrimination in different species may thus be linked to differential selection pressures.

\section{Sex allocation}

Ants, like all Hymenoptera, are haplodiploid, meaning that unfertilized, haploid eggs give rise to males, whereas fertilized, diploid eggs give rise to females. This mode of sex determination results in relatedness asymmetries between a singly mated mother queen and her male and female offspring: while the queen is equally related to offspring of both sexes (relatedness coefficient $r=0.5$ ), female offspring are, on average, more closely related to each other $(r=0.75)$ than they are to their brothers $(r=0.25)$. Relatedness asymmetries resulting from 
haplodiploidy can cause conflict to arise between queens and workers over the sex of brood. In colonies with a single, singly inseminated queen, workers prefer investing more in female production (specifically production of new queens, so-called gynes), while the queen prefers equal investment in both sexes (Trivers and Hare 1976). Whether an egg is fertilized is thought to be under the direct control of the queen herself (Ratnieks and Keller 1998), allowing her to modulate the primary sex ratio of brood (Passera et al. 2001; Rosset and Chapuisat 2006). However, workers can attempt to bias secondary sex ratios, i.e., investment towards gynes, by destroying male brood or biasing caste fate of diploid brood (Helanterä and Ratnieks 2009b). In species where workers have retained the ability to produce haploid eggs, they may also attempt to replace the queen's sons with their own (Wenseleers and Ratnieks 2006).

For adults to be able to selectively destroy male brood or preferentially rear gynes, they must be able to discriminate between male and female brood (Nonacs and Carlin 1990). A number of studies have approached this question by comparing the primary and secondary sex ratios produced by natural colonies and inferring selective removal of males (Brian 1981; Nonacs and Carlin 1990; Edwards 1991; Passera et al. 1995; Aron et al. 1995; Jemielity and Keller 2003; Rosset and Chapuisat 2006; Warner et al. 2016). However, although it is clear that workers can discriminate between sexes, and that this behavior depends on factors such as brood developmental stage, queen presence and queen number (Table 1), next to nothing is known about the cues involved. Sex-specific recognition cues are probably not directly linked to the ploidy state of eggs, since queen-laid male eggs would otherwise be destroyed in the process. In line with this, F. selysi workers are able to discriminate haploid worker-laid eggs from haploid queen-laid eggs, probably with the help of queenderived odors on the egg surface (Meunier et al. 2010). As the sex allocation preferences of queens and workers vary with colony kin structure (Bourke and Franks 1995b), this should also influence whether brood are under selection to mask or signal sex (Nonacs and Carlin 1990; Schultner et al. 2017). In the past, comparisons of sex-specific brood traits, and in particular brood odor profiles, were hindered by the lack of appropriate methods with which researchers themselves could differentiate between the sexes. Fortunately, a recent study describing differences in male and female genital disc morphology in larvae has taken a first step towards overcoming this hurdle (Penick et al. 2014). In the future, systematic studies of sexspecific brood traits across different kin structures will help us understand the causes and constraints of brood discrimination according to sex.

\section{Caste allocation}

Adult queens and workers differ in their relatedness to developing females because of haplodiploidy; this relatedness asymmetry can cause them to exhibit differing fitness interests regarding allocation of resources toward new queens (Beekman and Ratnieks 2003; Ratnieks et al. 2006). In addition, female larvae are predicted to be under selection to increase their chances of developing into a queen rather than a worker, since a female is more closely related to her own offspring than to offspring of other developing individuals (Bourke and Ratnieks 1999; Dobata 2012). In ants, caste determination factors are manifold and range from intrinsic traits such as genotype (Helms Cahan and Keller 2003) to social environmental factors such as worker behavior (Penick and Liebig 2012). In species with genetic caste determination, caste differences should manifest early on in development and information on caste should, in principle, be available to rearing workers throughout the course of development. In species with environmental caste determination, differences are predicted to manifest sometime during larval development or during pupation. As queens are larger than workers in most species, the trait most commonly associated with queen caste during development is body size (Trible and Kronauer 2017). Accordingly, in the fire ant Solenopsis invicta larval body size correlates with the rate, but not duration, of trophallaxis between workers and larvae (Cassill and Tschinkel 1995, 1999). In contrast, larval size had no effect on worker brood care behavior in the ant Myrmica rubra (Brian 1975b). Because of limited knowledge on the timing of caste determination across the ant phylogeny, only a handful of studies have attempted to find morphological, physiological or chemical traits associated with female caste. Nevertheless, there is sufficient evidence showing that workers adjust their behavior according to the caste of female brood (Table 1). Brian (1975a) for example found that queen-potential Myrmica larvae secrete oily droplets, and that workers preferentially fed secreting larvae; as a result, secreting larvae more often developed into queens. In the presence of an adult queen; however, queen-potential larvae were repeatedly attacked and bitten, causing them to develop into workers (Brian 1970, 1973b). A similar phenomenon was observed in the ant Harpegnathos saltator, in which queen and workerdestined larvae differ in their hydrocarbon profiles and workers preferentially bite queen-destined larvae in the presence of an adult queen (Penick and Liebig 2017). In queen-right Linepithema humile colonies, queen-destined larvae are also killed selectively, while queen-destined pupae, worker brood and male brood are spared (Passera et al. 1995). Worker behavior towards worker- and 
queen-destined larvae also differs in Aphaenogaster gracilis, even though the hydrocarbon profiles of the two castes are highly similar (Villalta et al. 2016). Thus, while there is little doubt that workers can differentiate brood according to caste, and that this ability is not phylogenetically constrained, more studies are needed to draw conclusions about the cues involved.

\section{Interactions with conspecifics}

In the context of conspecific interactions, accepting nonnestmate worker brood can be beneficial, since workers can successfully integrate into an adoptive colony, without the resources needed to rear them. In fact, in some species conspecific brood theft is a common strategy to increase growth and ensure survival of incipient colonies (Pollock and Rissing 1989; Paul et al. 2016). In contrast, non-nestmate sexual brood should not be accepted indiscriminately, since maleand queen-destined individuals may use colony resources without contributing to colony fitness. Concordantly, in the ant Formica exsecta, workers retrieve both nestmate and non-nestmate worker pupae at similar rates but prefer nestmate sexual pupae to non-nestmates (Pulliainen et al. 2018). These results highlight why discrimination against non-nestmate brood can be beneficial in some contexts but not in others and may help explain the broad range of results reported by studies on conspecific brood discrimination. For example, workers of the ant Formica fusca discriminate between nestmate and non-nestmate eggs only when an adult queen is present in the colony (Helanterä and Sundström 2007) and when they have been exposed to nestmate eggs during the first few days of adult life (Helanterä et al. 2007; Helanterä and Ratnieks 2009a). Removal of the queen and exposure to alien eggs during the sensitive period strongly reduce discrimination between nestmate and non-nestmate brood. In contrast, workers of the closely related species Formica gnava do not seem to discriminate between nestmate and non-nestmate pupae, even when the queen is present (Goodloe and Topoff 1987). Such differential responses may be explained by development stage-specific responses or species-specific ecologies. One explanation for precise discrimination between nestmate and non-nestmate eggs in $F$. fusca is the potential threat of intraspecific parasitism, which occurs when a founding queen takes over an established conspecific colony and hijacks its workforce. Low relatedness among $F$. fusca nestmate queens (Hannonen et al. 2004; Bargum et al. 2007) and the fact that even larvae seem to discriminate between nestmate and nonnestmate eggs (Pulliainen et al. 2019) support the idea that intraspecific parasitism shapes discrimination abilities in this species. Together, these results underline that phylogeny, ecology and within-colony social context are major factors mediating conspecific brood discrimination.

\section{Interactions with heterospecifics}

Ants are known to accept and rear heterospecific brood (Table 3). At the same time, the preference for familiar brood, especially when given a choice between con- and heterospecifics, is generally high, and pupa-carrying assays have been used as a taxonomic tool (Rosengren and Cherix 1981; Rosengren et al. 1994; Maeder et al. 2005). In addition, patterns of discrimination against heterospecific brood mirror phylogeny to a certain extent, so that more closely related species are more likely to rear each other's brood (Carlin 1988). Clearly, ant workers are capable of recognizing and discriminating against heterospecific brood. However, if they do so, depends on ecological context and the biology of the species.

The ability to discriminate against foreign brood is especially important in species that are targeted by heterospecific ant social parasites. These are numerous in ants and fall into three groups: permanent inquilines, slave-makers, and temporary social parasites (Hölldobler and Wilson 1990; Buschinger 2009). While permanent inquilines coexist with the host species, slave-making ants raid other colonies to capture and enslave their brood (Hölldobler and Wilson 1990; d'Ettorre and Heinze 2001). Queens of temporary social parasite species invade host colonies, kill the host queen(s), and take advantage of the brood care behavior of host workers to rear their eggs (Buschinger 2009). In all three cases, hosts may benefit from the ability to discriminate against parasite brood. However, this ability appears to vary among potential host species, and discriminatory behavior can be influenced by social context, e.g., the presence of conspecific brood. In addition, the identity of the intruder plays an important role in determining whether discrimination occurs. For instance, some hosts of slave-making species do not discriminate against brood of the slave-maker but do discriminate against other heterospecific brood (Alloway and Hare 1989; Zimmerli and Mori 1993; Mori et al. 1996). Failure to discriminate against parasite brood may be linked to chemical similarity between host and parasite brood (Lenoir et al. 2001b; Johnson et al. 2005). Such chemical deception is also employed by non-ant parasites such as Maculinae butterfly larvae, whose odors closely resemble those of the larvae of its ant host (Akino et al. 1999). However, not all parasite brood mimics host odors. For example, the pupal profiles of the slave-making ant Protomognathus americanus and its hosts (Temnothorax longispinosus, $T$. curvispinosus, T. ambiguous) are highly divergent (Achenbach et al. 2010), and hosts may use this information to discriminate against slave-maker brood (Achenbach and Foitzik 2009). Hosts and their parasites are typically locked in an evolutionary arms race, with hosts under selection to detect and remove parasites, and parasites under selection to avoid detection (Davies et al. 1989). The dynamics of such systems 
may explain differences in brood discrimination behavior between species.

The complexity of host-parasite interactions and how they influence discrimination is perhaps best exemplified by studies of the ant Formica fusca. This species is a common host to temporary social parasites, whose queens found their colonies in the host nest (Punttila 1996). In populations with high parasite pressure, $F$. fusca exhibits excellent discrimination abilities, and both adult workers and larvae can discriminate against non-nestmate conspecific and heterospecific eggs (Helanterä and Sundström 2007; Helanterä et al. 2007, 2014; Helanterä and Ratnieks 2009a; Chernenko et al. 2011, 2013; Martin et al. 2011; Pulliainen et al. 2019), most likely with the help of colony-specific egg odors (Helanterä and d'Ettorre 2014). Whether discrimination actually occurs depends on factors such as queen presence and exposure of young workers to foreign odors (Helanterä and Sundström 2007; Helanterä et al. 2007; Helanterä and Ratnieks 2009a; Chernenko et al. 2013). In contrast, in populations without parasites, worker discrimination abilities as well as chemical diversity of egg surface cues are strongly reduced (Martin et al. 2011). Thus, in this species, discrimination against social parasites is mediated by the interaction of colony phenotype, worker ontogeny and species community ecology. Population-specific patterns of parasite brood discrimination have been demonstrated in other species (Achenbach et al. 2010; Solazzo et al. 2013), indicating that local adaptation plays an important role in shaping discrimination behavior.

\section{Brood recognition: the importance of context}

Recognition and discrimination in ants are highly contextdependent (Fig. 1). As it stands, it is sometimes difficult to disentangle whether the species-specific differences in brood discrimination reviewed here are phylogenetically determined or rather due to differences in ontogeny, ecology, or experimental design. For example, the references outlined in Tables 1, 2 and 3 illustrate that phylogeny is not a clear-cut determinant of brood recognition and discrimination abilities, as species belonging to the same genera (e.g., Myrmica, Formica) can differ immensely in their behavioral responses, even when they occupy similar ecological niches. In the final section of our review, we highlight ecological and experimental factors that have been shown to influence discrimination processes, and which may explain some of the contrasting patterns observed in previous studies.

\section{Queen presence and number}

The presence of the queen(s) has an important impact on key aspects of colony life such as worker reproduction and female caste determination. Queen presence can also influence the brood recognition and discrimination behavior of workers (Brian 1973b, c; Vargo and Fletcher 1986; Edwards 1991; Passera et al. 1995; Klobuchar and Deslippe 2002; d'Ettorre et al. 2004; Helanterä and Sundström 2007; Vienne et al. 2010; Villalta et al. 2016). Compared to queen-right colonies, orphaned Formica fusca colonies for instance discriminate less against conspecific non-nestmate (Helanterä and Sundström 2007) and heterospecific eggs (Chernenko et al. 2013).

Monogynous (one reproductive queen) and monodomous (one nest) colonies may exhibit better nestmate discrimination abilities compared to polygynous and polydomous colonies (Sundström 1997; Martin et al. 2009). In the context of brood discrimination, experiments with the socially polymorphic ant $F$. selysi indicate that this is linked to differences in brood odor profiles from monogynous and polygynous nests, and not to differential discrimination abilities of monogyne and polygyne workers. In this species, workers from both monogyne and polygyne colonies were able to discriminate against foreign monogyne eggs, whereas neither was were able to discriminate against foreign polygyne eggs (Meunier et al. 2010, 2011), suggesting that queen number influences signalers more than receivers. Concordantly, the hydrocarbon profiles of eggs are specific to social origin, so that polygyne eggs, more often than monogyne eggs, lack reliable colony-specific cues. Similarly, Formica lugubris workers from monogyne but not polygyne colonies show a slight preference for nestmate eggs (Maeder et al. 2005), but whether this is linked to egg surface chemistry is not known. Overall, cue scrambling in polygyne eggs may have evolved to prevent workers from discriminating between eggs from different matrilines in polygyne colonies (but see Helanterä and d'Ettorre 2014). This is in line with evolutionary predictions that kin-informative cues should be selected against to avoid colony-level costs associated with kin-preferential treatment (Ratnieks 1991; Keller 1997; Ratnieks et al. 2006).

\section{Experimental constraints}

There are several constraints that need to be considered when interpreting the results of discrimination studies. First, failure to detect discrimination does not necessarily translate into lack of recognition. Thus, even in studies that do not detect discrimination, workers may recognize brood of different origins but refrain from differential treatment (Pulliainen et al. 2018). Second, discrimination against brood is usually not an all-or-none process. Thus, the insight we gain from experiments testing only one type of brood (e.g., only heterospecific brood) are limited, since worker preferences may change when they are given a choice, for instance between con- and heterospecific brood. For example, Leptothorax nylanderi and Tapinoma erraticum workers fail to discriminate against 
heterospecific brood when no other brood is present but show a clear preference for conspecific brood when con- and heterospecific brood are presented simultaneously (Plateaux 1960a; Meudec 1978). Furthermore, even though alien brood may at first be accepted, discrimination can still occur, for instance in the form of later neglect or consumption (Jaisson 1975; Jaisson and Fresneau 1978; Le Moli and Passetti 1978; Johnson et al. 2005; Chernenko et al. 2011, 2013). The conditions under which brood are obtained for experiments may also affect experimental outcomes: in Neoponera inversa, eggs from lab and field colonies differ in their cuticular profiles. When worker-laid eggs sampled from lab colonies were treated with a synthetic queen-derived compound, they elicited aggressive treatment by workers. In contrast, worker-laid eggs from field colonies treated with the same compound did not elicit worker aggression (van Zweden et al. 2009b).

Third, discrimination tests in the past have often used frozen rather than fresh brood. This can have a strong effect on the way workers treat brood. Atta cephalotes workers for instance retrieve living larvae significantly more often than dead larvae but do not seem to distinguish between dead and living pupae (Robinson and Cherrett 1974). Using dead brood may affect worker behavior if discrimination is based on acoustic signals (as appears to be the case in Myrmica scabrinodis, Casacci et al. 2013), or if workers use behavioral cues to recognize brood. This may be especially relevant in the case of discrimination of larvae, since this is the only mobile developmental stage. Indeed, even though A. cephalotes workers differentiate between dead and live larvae, they do not react to odor extracts from live larvae (Robinson and Cherrett 1974), suggesting that larval behavior, not odor, is crucial for recognition in this species.

Finally, special care must be taken to avoid confusing brood retrieval behavior with other behaviors, in particular food foraging behavior. This may be especially relevant in cases, where colonies have been starved prior to experiments, since brood represents an excellent food source. Furthermore, ant foragers can use chemical cues to identify suitable food items, and these cues may overlap with brood chemical cues (Viana et al. 2001). Specificity of brood cues has been a much-discussed challenge in the field (Walsh and Tschinkel 1974; Morel and Vander Meer 1988; Vander Meer and Morel 1988), and we refer the interested reader to Tschinkel (2006), who thoroughly reviewed the data on brood recognition cues in fire ants, the best studied ant species in this (and many other) respects.

\section{Conclusion}

Our review of the literature has shown that, while brood discrimination is generally less stringent than discrimination against adults, it can be important in a number of fitness-related contexts. Carlin (1988, page 283) summarized four features of brood recognition in ants: "(1) potent generalized brood stimuli, (2) sufficient similarity in brood stimuli to facilitate acceptance across kin, colony and species categories, (3) sufficient variation in brood stimuli to enable non-exclusive discrimination of kin, nestmates and species and (4) learned recognition of colony- and species-specific variants of the stimuli." To these, we can now add (5) sufficient variation in brood stimuli to enable discrimination according to viability, developmental stage, sex, and caste, (6) strong context dependency and influence of individual phenotype and social environment, and (7) wide diversity in brood stimuli, including brood surface chemistry, secretions, morphology, and behavior, that can act alone or together. In spite of these advances, many open questions remain about brood-directed behavior, and more generally, about social interactions involving brood in ants. As the role of development in driving evolutionary processes receives more attention, studies focusing on brood-adult interactions are beginning to provide insight into the physiological and genetic mechanisms underlying these complex interaction networks (Chandra et al. 2018; Walsh et al. 2018b; Warner et al. 2019) and their evolutionary basis (Walsh et al. 2018a). Hopefully, this review will help inspire future research on the fascinating life of ant brood.

Acknowledgments Open Access funding provided by Projekt DEAL. This work was supported by the Bayrisches Staatsministerium für Bildung und Kultus, Wissenschaft und Kunst (E.S.) and the LUOVA Doctoral Programme (U.P.). The authors thank Jan Oettler, Jürgen Heinze, Miriam Richards and two anonymous reviewers for comments on previous versions of the manuscript.

Open Access This article is licensed under a Creative Commons Attribution 4.0 International License, which permits use, sharing, adaptation, distribution and reproduction in any medium or format, as long as you give appropriate credit to the original author(s) and the source, provide a link to the Creative Commons licence, and indicate if changes were made. The images or other third party material in this article are included in the article's Creative Commons licence, unless indicated otherwise in a credit line to the material. If material is not included in the article's Creative Commons licence and your intended use is not permitted by statutory regulation or exceeds the permitted use, you will need to obtain permission directly from the copyright holder. To view a copy of this licence, visit http://creativecommons.org/licenses/by/4.0/.

\section{References}

Achenbach A, Foitzik S (2009) First evidence for slave rebellion: enslaved ant workers systematically kill the brood of their social parasite Protomognathus americanus. Evolution 63:1068-1075. https://doi.org/10.1111/j.1558-5646.2009.00591.x

Achenbach A, Witte V, Foitzik S (2010) Brood exchange experiments and chemical analyses shed light on slave rebellion in ants. Behav Ecol 21:948-956. https://doi.org/10.1093/beheco/arq008 
Akino T, Yamaoka R (1998) Chemical mimicry in the root aphid parasitoid Pavalipsis eikoae Yasumatsu (Hymenoptera: Aphidiidae) of the aphid-attending ant Lasius sakagamii Yamauchi \& Hayashida (Hymenoptera: Formicidae). Chemoecology 8:153161. https://doi.org/10.1007/s000490050020

Akino T, Knapp JJ, Thomas JA, Elmes GW (1999) Chemical mimicry and host specificity in the butterfly Maculinea rebeli, a social parasite of Myrmica ant colonies. Proc R Soc B Biol Sci 266:1419-1426. https://doi.org/10.1098/rspb.1999.0796

Alloway T, Hare JF (1989) Experience-independent attraction to slavemaker ant larvae in host species ant workers (Leptothorax longispinosus; Hymenoptera: Formicidae). Behavior 110:93-105. https ://www.jstor.org/stable/4534786

Araujo M, Della Lucia T, Araujo F, Bento J (1996) Discriminação da prole por operárias companheiras e não companheiras de ninho em Atta sexdens rubropilosa Forel, 1908 (Hymenoptera, Formicidae). Rev Bras Entomol 40:101-104

Aron S, Passera L, Keller L (1994) Queen-worker conflict over sex ratio: a comparison of primary and secondary sex ratios in the Argentine ant, Iridomyrmex humilis. J Evol Biol 7:403-418. https ://doi.org/10.1007/s10958-007-0251-x

Aron S, Vargo EL, Passera L (1995) Primary and secondary sex ratios in monogyne colonies of the fire ant. Anim Behav 49:749-757. https://doi.org/10.1016/0003-3472(95)80207-X

Aron S, Passera L, Keller L (2004) Evolution of miniaturisation in inquiline parasitic ants: timing of male elimination in Plagiolepis pygmaea, the host of Plagiolepis xene. Insectes Soc 51:395-399. https://doi.org/10.1007/s00040-004-0758-9

Bagnères AG, Morgan ED (1991) The postpharyngeal glands and the cuticle of Formicidae contain the same characteristic hydrocarbons. Experientia 47:106-111. https://doi.org/10.1007/BF020 41269

Bargum K, Helanterä H, Sundström L (2007) Genetic population structure, queen supersedure and social polymorphism in a social Hymenoptera. J Evol Biol 20:1351-1360. https://doi. org/10.1111/j.1420-9101.2007.01345.x

Baroni Urbani C (1991) Indiscriminate oophagy by ant larvae: an explanation for brood serial organization? Insectes Soc 38:229-239. https://doi.org/10.1007/BF01314909

Beekman M, Ratnieks FLW (2003) Power over reproduction in social Hymenoptera. Philos Trans R Soc B Biol Sci 358:1741-1753. https://doi.org/10.1098/rstb.2002.1262

Bigley W, Vinson SB (1975) Characterization of a brood pheromone isolated from sexual brood of the imported fire ant, Solenopsis invicta. Ann Entomol Soc Am 68:301-304. https://doi. org/10.1093/aesa/68.2.301

Blatrix R, Sermage C (2005) Role of early experience in ant enslavement: a comparative analysis of a host and a non-host species. Front Zool 2:1-7. https://doi.org/10.1186/1742-9994-2-13

Blomquist GJ, Bagnères A-G (eds) (2010) Insect hydrocarbonsbiology, biochemistry and chemical ecology. Cambridge University Press, Cambridge

Boomsma JJ, d'Ettorre P (2013) Nice to kin and nasty to non-kin: revisiting Hamilton's early insights on eusociality. Biol Lett 9:20130444. https://doi.org/10.1098/rsbl.2013.0444

Boomsma JJ, Isaaks J (1985) Energy investment and respiration in queens and males of Lasius niger (Hymenoptera: Formicidae). Behav Ecol Sociobiol 18:19-27. https://doi.org/10.1007/ BF00299234

Bos N, Grinsted L, Holman L (2011) Wax on, wax off: nest soil facilitates indirect transfer of recognition cues between ant nestmates. PLoS One 6:e19435. https://doi.org/10.1371/journ al.pone. 0019435

Boulay R, Hefetz A, Soroker V, Lenoir A (2000) Camponotus fellah colony integration: worker individuality necessitates frequent hydrocarbon exchanges. Anim Behav 59:1127-1133. https:// doi.org/10.1006/anbe.2000.1408

Bourke AFG (1991) Queen behaviour, reproduction and egg cannibalism in multiple-queen colonies of the ant Leptothorax acervorum. Anim Behav 42:295-310. https://doi.org/10.1016/ S0003-3472(05)80561-5

Bourke AFG (1994) Indiscriminate egg cannibalism and reproductive skew in a multiple-queen ant. Proc R Soc B Biol Sci 255:55-59. https://doi.org/10.1098/rspb.1994.0008

Bourke AFG, Franks NR (1995a) Social evolution in ants. Princeton University Press, Princeton

Bourke AFG, Franks NR (1995b) Kin conflict over sex allocation. Social evolution in ants. Princeton University Press, Princeton, pp 200-218

Bourke AFG, Ratnieks FLW (1999) Kin conflict over caste determination in social Hymenoptera. Behav Ecol Sociobiol 46:287297. https://doi.org/10.1007/s002650050622

Brandstaetter AS, Rössler W, Kleineidam CJ (2011) Friends and foes from an ant brain's point of view-neuronal correlates of colony odors in a social insect. PLoS One 6:e21383. https:// doi.org/10.1371/journal.pone.0021383

Brian MV (1970) Communication between queens and larvae in the ant Myrmica. Anim Behav 18:467-472. https://doi. org/10.1016/0003-3472(70)90041-2

Brian MV (1973a) Temperature choice and its relevance to brood survial and caste determination in the ant Myrmica rubra L. Physiol Zool 46:245-252. https://doi.org/10.1086/physz ool.46.4.30155608

Brian MV (1973b) Caste control through worker attack in the ant Myrmica. Insectes Soc 20:87-102. https://doi.org/10.1007/ BF02223340

Brian MV (1973c) Queen recognition by brood-rearing workers of the ant Myrmica rubra L. Anim Behav 21:691-698. https://doi. org/10.1016/S0003-3472(73)80093-4

Brian MV (1975a) Larval recognition by workers of the ant $M y r-$ mica. Anim Behav 23:745-756. https://doi.org/10.1016/00033472(75)90102-5

Brian MV (1975b) Caste determinaton through a queen influence on diapause in larvae of the ant Myrmica rubra. Entomol Exp Appl 18:429-442. https://doi.org/10.1111/j.1570-7458.1975. tb00420.x

Brian MV (1981) Treatment of male larvae in ants of the genus Myrmica. Insectes Soc 28:161-166. https://doi.org/10.1007/ BF02223702

Brian MV, Abbott A (1977) The control of food flow in a society of the ant Myrmica rubra L. Anim Behav 25:1047-1055. https:// doi.org/10.1016/0003-3472(77)90055-0

Brian MV, Carr C (1960) The influence of the queen on brood rearing in ants of the genus Myrmica. J Insect Physiol 5:81-94. https://doi.org/10.1016/0022-1910(60)90034-2

Buschinger A (2009) Social parasitism among ants: a review (Hymenoptera: Formicidae). Myrmecol News 12:219-235

Carlin NF (1988) Species, kin and other forms of recognition in the brood discrimination behavior of ants. In: Trager J (ed) Advances in myrmecology. E.J. Brill, New York, pp 267-295

Carlin NF, Schwartz PH (1989) Pre-imaginal experience and nestmate brood recognition in the carpenter ant, Camponotus floridanus. Anim Behav 38:89-95. https://doi.org/10.1016/S0003 -3472(89)80068-5

Carlin NF, Halpern R, Hölldobler B, Schwartz P (1987) Early learning and the recognition of conspecific cocoons by carpenter ants (Camponotus spp.). Ethology 75:306-316. https://doi. org/10.1111/j.1439-0310.1987.tb00662.x

Casacci LP, Thomas J, Sala M et al (2013) Ant pupae employ acoustics to communicate social status in their colony's 
hierarchy. Curr Biol 23:323-327. https://doi.org/10.1016/j. cub.2013.01.010

Cassill DL, Tschinkel WR (1995) Allocation of liquid food to larvae via trophallaxis in colonies of the fire ant, Solenopsis invicta. Anim Behav 50:801-813. https://doi.org/10.1016/00033472(95)80140-5

Cassill DL, Tschinkel WR (1996) A duration constant for worker-tolarva trophallaxis in fire ants. Insectes Soc 43:149-166. https:// doi.org/10.1007/BF01242567

Cassill DL, Tschinkel WR (1999) Regulation of diet in the fire ant, Solenopsis invicta. J Insect Behav 12:307-328. https://doi. org/10.1023/A:1020835304713

Chandra V, Fetter-Pruneda I, Oxley PR et al (2018) Social regulation of insulin signaling and the evolution of eusociality in ants. Science 361:398-402. https://doi.org/10.1126/science.aar5723

Chernenko A, Helanterä H, Sundström L (2011) Egg recognition and social parasitism in Formica ants. Ethology 117:1081-1092. https://doi.org/10.1111/j.1439-0310.2011.01972.x

Chernenko A, Vidal-Garcia M, Helanterä H, Sundström L (2013) Colony take-over and brood survival in temporary social parasites of the ant genus Formica. Behav Ecol Sociobiol 67:727-735. https ://doi.org/10.1007/s00265-013-1496-7

Chung H, Carroll SB (2015) Wax, sex and the origin of species: dual roles of insect cuticular hydrocarbons in adaptation and mating. BioEssays 37:822-830. https://doi.org/10.1002/bies.201500014

Creemers B, Billen J, Gobin B (2003) Larval begging behaviour in the ant Myrmica rubra. Ethol Ecol Evol 15:261-272. https://doi. org/10.1080/08927014.2003.9522671

Crespi B (1992) Cannibalism and trophic eggs in subsocial and eusocial insects. In: Elgar M, Crespi B (eds) Cannibalism: ecology and evolution among diverse taxa. Oxford University Press, New York City, pp 176-213

Crosland MWJ (1988) Inability to discriminate between related and unrelated larvae in the ant Rhytidoponera confusa (Hymenoptera: Formicidae). Ann Entomol Soc Am 81:844-850. https:// doi.org/10.1093/aesa/81.5.844

Cuvillier-Hot V, Cobb M, Malosse C, Peeters C (2001) Sex, age and ovarian activity affect cuticular hydrocarbons in Diacamma ceylonense, a queenless ant. J Insect Physiol 47:485-493. https://doi. org/10.1016/S0022-1910(00)00137-2

Cuvillier-Hot V, Lenoir A, Crewe R et al (2004) Fertility signalling and reproductive skew in queenless ants. Anim Behav 68:1209-1219. https://doi.org/10.1016/j.anbehav.2003.11.026

Czaczkes TJ, Grüter C, Ratnieks FLW (2014) Trail pheromones: an integrative view of their role in social insect colony organization. Annu Rev Entomol 60:581-599. https://doi.org/10.1146/annur ev-ento-010814-020627

d'Ettorre P, Heinze J (2001) Sociobiology of slave-making ants. Acta Ethol 3:67-82. https://doi.org/10.1007/s102110100038

d'Ettorre P, Lenoir A (2010) Nestmate recognition. In: Lach L, Parr C, Abbott K (eds) Ant ecology. Oxford University Press, Oxford, pp 194-208

d'Ettorre P, Heinze J, Ratnieks FLW (2004) Worker policing by egg eating in the ponerine ant Pachycondyla inversa. Proc R Soc B Biol Sci 271:1427-1434. https://doi.org/10.1098/rspb.2004.2742

d'Ettorre P, Tofilski A, Heinze J, Ratnieks FLW (2006) Non-transferable signals on ant queen eggs. Naturwissenschaften 93:136-140. https://doi.org/10.1007/s00114-005-0075-9

Dahbi A, Hefetz A, Cerdá X, Lenoir A (1999) Trophallaxis mediates uniformity of colony odor in Cataglyphis iberica ants (Hymenoptera, Formicidae). J Insect Behav 12:559-567. https://doi. org/10.1023/A:1020975009450

Davies NB, Bourke AFG, de Brooke LM (1989) Cuckoos and parasitic ants: interspecific brood parasitism as an evolutionary arms race. Trends Ecol Evol 4:274-278. https://doi.org/10.1016/01695347(89)90202-4
Delattre O, Châline N, Chameron S et al (2012) Social parasite pressure affects brood discrimination of host species in Temnothorax ants. Anim Behav 84:445-450. https://doi.org/10.1016/j.anbeh av.2012.05.020

Dietemann V (2002) Differentiation in reproductive potential and chemical communication of reproductive status in workers and queens of the ant Myrmecia gulosa. PhD thesis, Julius-MaximiliansUniversität Würzburg, Germany. urn:nbn:de:bvb:20-opus-2202

Dietemann V, Peeters C (2000) Queen influence on the shift from trophic to reproductive eggs laid by workers of the ponerine ant Pachycondyla apicalis. Insectes Soc 47:223-228. https://doi. org/10.1007/PL00001707

Dietemann V, Peeters C, Liebig J et al (2003) Cuticular hydrocarbons mediate discrimination of reproductives and nonreproductives in the ant Myrmecia gulosa. Proc Natl Acad Sci USA 100:1034110346. https://doi.org/10.1073/pnas.1834281100

Dietemann V, Liebig J, Hölldobler B, Peeters C (2005) Changes in the cuticular hydrocarbons of incipient reproductives correlate with triggering of worker policing in the bulldog ant Myrmecia gulosa. Behav Ecol Sociobiol 58:486-496. https://doi. org/10.1007/s00265-005-0939-1

Dobata S (2012) Arms race between selfishness and policing: twotrait quantitative genetic model for caste fate conflict in eusocial Hymenoptera. Evolution (N Y) 66:3754-3764. https://doi.org/1 0.1111/j.1558-5646.2012.01745.x

Drescher J, Blüthgen N, Schmitt T et al (2010) Societies drifting apart? Behavioural, genetic and chemical differentiation between supercolonies in the yellow crazy ant Anoplolepis gracilipes. PLoS One 5:e13581. https://doi.org/10.1371/journal.pone.0013581

Ebie JD, Hölldobler B, Liebig J (2015) Larval regulation of worker reproduction in the polydomous ant Novomessor cockerelli. Sci Nat 102:72. https://doi.org/10.1007/s00114-015-1323-2

Edwards J (1991) Caste regulation in the pharaoh's ant Monomorium pharaonis: recognition and cannibalism of sexual brood by workers. Physiol Entomol 16:263-271. https://doi. org/10.1111/j.1365-3032.1991.tb00565.x

Elgar M, Crespi B (eds) (1992) Cannibalism: ecology and evolution among diverse taxa. Oxford University Press, New York City

Elmes GW, Wardlaw JC (1983) A comparison of the effect of a queen upon the development of the large hibernated larvae of six species of the genus Myrmica (Hym. Formicidae). Insectes Soc 30:134-148. https://doi.org/10.1007/BF02223864

Elmes GW, Akino T, Thomas JA et al (2002) Interspecific differences in cuticular hydrocarbon profiles of Myrmica ants are sufficiently consistent to explain host specificity by Maculinea (large blue) butterflies. Oecologia 130:525-535. https://doi.org/10.1007/ s00442-001-0857-5

Endler A, Liebig J, Schmitt T et al (2004) Surface hydrocarbons of queen eggs regulate worker reproduction in a social insect. Proc Natl Acad Sci USA 101:2945-2950. https://doi.org/10.1073/ pnas.0308447101

Endler A, Liebig J, Hölldobler B (2006) Queen fertility, egg marking and colony size in the ant Camponotus floridanus. Behav Ecol Sociobiol 59:490-499. https://doi.org/10.1007/s0026 5-005-0073-0

Errard C (1984) Evolution, en fonction de l'age, des relations sociales dans les colonies mixtes heterospecifiques chez les fourmis des genres Camponotus et Pseudomyrmex. Insectes Soc 31:185-198. https://doi.org/10.1007/BF02232714

Errard C, Lenoir A, Francoeur A (1992) Effects of early experience on interactions between the parasite ant Formicoxenus provancheri and its host Myrmica incompleta (Hymenoptera: Formicidae). Anim Behav 43:787-794. https://doi.org/10.1016/S0003 -3472(05)80201-5

Evans JD (1995) Relatedness threshold for the production of female sexuals in colonies of a polygynous ant, Myrmica tahoensis, as 
revealed by microsatellite DNA analysis. Proc Natl Acad Sci USA 92:6514-6517. https://doi.org/10.1073/pnas.92.14.6514

Febvay G, Mallet F, Kermarrec A (1984) Attractivité du couvain et comportement des ouvrières de la fourmi Attine Acromymrex octospinosus (Reich) (Hym. Formicidae). Actes 1:79-86

Fénéron R, Jaisson P (1992) Nestmate-brood recognition among workers of different social status in Ectatomma tuberculatum Olivier (Formicidae, Ponerinae). Behav Processes 27:45-52. https://doi. org/10.1016/0376-6357(92)90039-G

Fénéron R, Jaisson P (1995) Ontogeny of nestmate brood recognition in a primitive ant, Ectatomma tubercalutum Olivier (Ponerinae). Anim Behav 50:9-14. https://doi.org/10.1006/anbe.1995.0215

Foitzik S, Sturm H, Pusch K et al (2007) Nestmate recognition and intraspecific chemical and genetic variation in Temnothorax ants. Anim Behav 73:999-1007. https://doi.org/10.1016/j.anbeh av.2006.07.017

Fouks B, d'Ettorre P, Nehring V (2011) Brood adoption in the leafcutting ant Acromyrmex echinatior: adaptation or recognition noise? Insectes Soc 58:479-485. https://doi.org/10.1007/s0004 0-011-0167-9

Fox EGP, Solis DR, Rossi ML et al (2011) Morphological notes on the worker and queen larvae of the thief ant Solenopsis helena (Hymenoptera, Formicidae, Myrmicinae) from Brazil. Florida Entomol 94(4):909-915. https://doi.org/10.1653/024.094.0427

Franks NR, Sendova-Franks AB (1992) Brood sorting by ants: distributing the workload over the work-surface. Behav Ecol Sociobiol 30:109-123. https://doi.org/10.1007/BF00173947

Gamboa GJ, Reeve HK, Holmes WG (1991) Conceptual issues and methodology in Kin-recognition research: a critical discussion. Ethology 88:109-127. https://doi. org/10.1111/j.1439-0310.1991.tb00267.x

Gibbs AG (1998) Water-proofing properties of cuticular lipids. Integr Comp Biol 38:471-482. https://doi.org/10.1093/icb/38.3.471

Gibbs AG, Rajpurohit S (2010) Cuticular lipids and water balance. In: Blomquist GJ, Bagnères A-G (eds) Insect Hydrocarbons: biology, biochemistry and chemical ecology. Cambridge University Press, Cambridge, pp 100-120

Glancey BM, Dickens J (1988) Behavioral and electrophysiological studies with live larvae and larval rinses of the red imported fire ant, Solenopsis invicta BUREN (Hymenoptera: Formicidae). J Chem Ecol 14:463-473. https://doi.org/10.1007/BF010 13898

Glancey BM, Stringer C, Craig C et al (1970) Pheromone may induce brood tending in the fire ant, Solenopsis saevissima. Nature 226:863-864. https://doi.org/10.1038/226863a0

Goodloe L, Topoff H (1987) Pupa acceptance by slaves of the socialparasitic ant Polyergus* (Hymenoptera: Formicidae). Psyche 94:293-302

Hammond RL, Bruford MW, Bourke AFG (2002) Ant workers selfishly bias sex ratios by manipulating female development. Proc R Soc B Biol Sci 269:173-178. https://doi.org/10.1098/ rspb.2001.1860

Hannonen M, Sundström L (2003) Worker nepotism among polygynous ants. Nature 421:910. https://doi.org/10.1038/421910a

Hannonen M, Helanterä H, Sundström L (2004) Habitat age, breeding system and kinship in the ant Formica fusca. Mol Ecol 13:15791588. https://doi.org/10.1111/j.1365-294X.2004.02136.x

Hare JF (1996) Discrimination of nestmate larvae by the ant Leptothorax longispinosus. Can J Zool 74:2055-2061. https://doi. org/10.1139/z96-233

Hare JF, Alloway T (1987) Early learning and brood discrimination in leptothoracine ants (Hymenoptera: Formicidae). Anim Behav 35:1720-1724. https://doi.org/10.1016/S0003-3472(87)80064-7

Hartmann A, Wantia J, Torres JA, Heinze J (2003) Worker policing without genetic conflicts in a clonal ant. Proc Natl Acad Sci USA 100:12836-12840. https://doi.org/10.1073/pnas.2132993100
Haskins CP, Haskins EF (1950) Notes on the biology and social behavior of the archaic ponerine ants of the genera Myrmecia and Promyrmecia. Ann Entomol Soc Am 43:461-491. https://doi. org/10.1093/aesa/43.4.461

Heinze J, Trunzer B, Oliveira PS, Hölldobler B (1996) Regulation of reproduction in the neotropical ponerine ant, Pachycondyla villosa. J Insect Behav 9:441-450. https://doi.org/10.1007/BF022 14021

Helanterä H, d'Ettorre P (2014) A comparative study of egg recognition signature mixtures in Formica ants. Evolution (N Y) 69:520 529. https://doi.org/10.1111/evo.12590

Helanterä H, Ratnieks FLW (2009a) Two independent mechanisms of egg recognition in worker Formica fusca ants. Behav Ecol Sociobiol 63:573-580. https://doi.org/10.1007/s00265-008-0692-3

Helanterä H, Ratnieks FLW (2009b) Sex allocation conflict in insect societies: who wins? Biol Lett 5:700-704. https://doi. org/10.1098/rsbl.2009.0501

Helanterä H, Sundström L (2005) Worker reproduction in the ant Formica fusca. J Evol Biol 18:162-171. https://doi.org/10.111 1/j.1420-9101.2004.00777.x

Helanterä H, Sundström L (2007) Worker policing and nest mate recognition in the ant Formica fusca. Behav Ecol Sociobiol 61:1143-1149. https://doi.org/10.1007/s00265-006-0327-5

Helanterä H, Martin SJ, Ratnieks FLW (2007) Prior experience with eggs laid by non-nestmate queens induces egg acceptance errors in ant workers. Behav Ecol Sociobiol 62:223-228. https://doi.org/10.1007/s00265-007-0456-5

Helanterä H, Lee YR, Drijfhout FP, Martin SJ (2011) Genetic diversity, colony chemical phenotype, and nest mate recognition in the ant Formica fusca. Behav Ecol 22:710-716. https://doi. org/10.1093/beheco/arr037

Helanterä H, Martin SJ, Ratnieks FLW (2014) Recognition of nestmate eggs in the ant Formica fusca is based on queen derived cues. Curr Zool 60:131-136. https://doi.org/10.1093/czool $\mathrm{o} / 60.1 .131$

Helms Cahan S, Keller L (2003) Complex hybrid origin of genetic caste determination in harvester ants. Nature 424:306-309. https ://doi.org/10.1038/nature01744

Hölldobler B, Carlin NF (1989) Colony founding, queen control and worker reproduction in the ant Aphaenogaster (=Novomessor) Cockerelli (Hymenoptera: Formicidae). Psyche 96:131-151. https://doi.org/10.1155/1989/74135

Hölldobler B, Wilson EO (1990) The ants. Belknap-Harvard University Press, Cambridge

Hölldobler B, Wilson EO (2009) The superorganism: the beauty, elegance, and strangeness of insect societies. W. W. Norton \& Company, New York

Holman L, Jørgensen CG, Nielsen J, d'Ettorre P (2010) Identification of an ant queen pheromone regulating worker sterility. Proc R Soc B Biol Sci 277:3793-3800. https://doi.org/10.1098/ rspb.2010.0984

Holzer B, Kümmerli R, Keller L, Chapuisat M (2006) Sham nepotism as a result of intrinsic differences in brood viability in ants. Proc R Soc B Biol Sci 273:2049-2052. https://doi.org/10.1098/ rspb.2006.3553

Isingrini M (1987) La reconnaissance coloniale des larves chez la fourmi Cataglyphis cursor (Hymenoptera, Formicidae). Insectes Soc 34:20-27. https://doi.org/10.1007/BF02224204

Isingrini M, Lenoir A (1988) Colony recognition of young workers of Cataglyphis cursor (Hymenoptera, Formicidae). Behav Process 17:69-72

Isingrini M, Lenoir A, Jaisson P (1985) Preimaginal learning as a basis of colony-brood recognition in the ant Cataglyphis cursor. Proc Natl Acad Sci USA 82:8545-8547. https://doi.org/10.1073/ pnas.82.24.8545 
Iwanishi S, Hasegawa E, Ohkawara K (2003) Worker oviposition and policing behaviour in the myrmicine ant Aphaenogaster smythiesi japonica FOREL. Anim Behav 66:513-519. https:// doi.org/10.1006/anbe.2003.2222

Jaisson P (1975) L'impregnation dans l'ontogenese des comportement de soins aux cocons chez la jeune fourmi rousse (Formica polyctena Först.). Behavior 52:1-37. https://www.jstor.org/stabl e/4533634

Jaisson P, Fresneau D (1978) The sensitivity and responsiveness of ants to their cocoons in relation to age and methods of measurement. Anim Behav 26:1064-1071. https://doi.org/10.1016/00033472(78)90095-7

Jemielity S, Keller L (2003) Queen control over reproductive decisions-no sexual deception in the ant Lasius niger. Mol Ecol 12:1589-1597. https://doi.org/10.1046/j.1365-294X.2003.01838 . $\mathrm{x}$

Johnson CA, Topoff H, Vander Meer RK, Lavine B (2005) Do these eggs smell funny to you? An experimental study of egg discrimination by hosts of the social parasite Polyergus breviceps (Hymenoptera: Formicidae). Behav Ecol Sociobiol 57:245-255. https ://doi.org/10.1007/s00265-004-0851-0

Kaptein N, Billen J, Gobin B (2005) Larval begging for food enhances reproductive options in the ponerine ant Gnamptogenys striatula. Anim Behav 69:293-299. https://doi. org/10.1016/j.anbehav.2004.04.012

Keller L (1997) Indiscriminate altruism: unduly nice parents and siblings. Trends Ecol Evol 12:99-103. https://doi.org/10.1016/ S0169-5347(96)10065-3

Keller L, Aron S, Passera L (1996) Internest sex-ratio variation and male brood survival in the ant Pheidole pallidula. Behav Ecol 7:292-298. https://doi.org/10.1093/beheco/7.3.292

Kikuta N, Tsuji K (1999) Queen and worker policing in the monogynous and monandrous ant, Diacamma sp. Behav Ecol Sociobiol 46:180-189. https://doi.org/10.1007/s002650050608

Kleeberg I, Menzel F, Foitzik S (2017) The evolution of cuticular hydrocarbons in ants: the influence of parasitic lifestyle, caste and sex on chemical profiles. Proc R Soc B Biol Sci 284:20162249. https://doi.org/10.1098/rspb.2016.2249

Klobuchar E, Deslippe R (2002) A queen pheromone induces workers to kill sexual larvae in colonies of the red imported fire ant (Solenopsis invicta). Naturwissenschaften 89:302-304. https ://doi.org/10.1007/s00114-002-0331-1

Krag K, Lundegaard R, Offenberg J et al (2010) Intercolony transplantation of Oecophylla smaragdina (Hymenoptera: Formicidae) larvae. J Asia Pac Entomol 13:97-100. https://doi. org/10.1016/j.aspen.2009.12.005

Kulmuni J, Havukainen H (2013) Insights into the evolution of the CSP gene family through the integration of evolutionary analysis and comparative protein modeling. PLoS One 8:e6368. https://doi.org/10.1371/journal.pone.0063688

Larsen J, Fouks B, Bos N et al (2014) Variation in nestmate recognition ability among polymorphic leaf-cutting ant workers. J Insect Physiol 70:59-66. https://doi.org/10.1016/j.jinsp hys.2014.09.002

Larsen J, Nehring V, d'Ettorre P, Bos N (2016) Task specialization influences nestmate recognition ability in ants. Behav Ecol Sociobiol 70:1433-1440. https://doi.org/10.1007/s0026 5-016-2152-9

Le Conte Y, Arnold G, Trouiller J, Masson C (1990) Identification of a brood pheromone in honeybees. Naturwissenschaften 77:334336. https://doi.org/10.1007/BF01138390

Le Conte Y, Mohammedi A, Robinson GE (2001) Primer effects of a brood pheromone on honeybee behavioural development. Proc R Soc B Biol Sci 268:163-168. https://doi.org/10.1098/ rspb.2000.1345
Le Conte Y, Bécard J-MJ, Costagliola G et al (2006) Larval salivary glands are a source of primer and releaser pheromone in honey bee (Apis mellifera L.). Naturwissenschaften 93:237-241. https ://doi.org/10.1007/s00114-006-0089-y

Le Masne G (1953) Observations sur les relations entre le couvain et les adultes chez les fourmis. Ann des Sci Nat Zool 15:1-56

Le Moli F (1978) Social influence on the acquisition of behavioural patterns in the ant Formica Rufa L. Ital J Zool 45:399-404. https ://doi.org/10.1080/11250007809440149

Le Moli F, Le Mori A (1982) Early learning and cocoon nursing behaviour in the red wood-ant Formica lugubris Zett. (Hymenoptera: Formicidae). Ital J Zool 49:93-97. https://doi.org/10.1080/11250 008209439376

Le Moli F, Passetti M (1977) The effect of early learning on recognition, acceptance and care of cocoons in the ant Formica rufa $\mathrm{L}$. Atti della Soc Ital di Sci Nat e del Mus Civ di Stor Nat di Milano 118:49-64

Le Moli F, Passetti M (1978) Olfactory learning phenomena and cocoon nursing behaviour in the ant Formica Rufa L. Bolletino di Zool 45:389-397. https://doi.org/10.1080/11250007809440148

Lenoir A (1981) Brood retrieving in the ant, Lasius niger L. Sociobiology $6: 153-178$

Lenoir A (1984) Brood-colony recognition in Cataglyphis cursor worker ants (Hymenoptera: Formicidae). Anim Behav 32:942944. https://doi.org/10.1016/S0003-3472(84)80189-X

Lenoir A, Cuisset D, Hefetz A (2001a) Effects of social isolation on hydrocarbon pattern and nestmate recognition in the ant Aphaenogaster senilis (Hymenoptera, Formicidae). Insectes Soc 48:101-109. https://doi.org/10.1007/PL00001751

Lenoir A, d'Ettorre P, Errard C, Hefetz A (2001b) Chemical ecology and social parasitism in ants. Annu Rev Entomol 46:573-599. https://doi.org/10.1146/annurev.ento.46.1.573

Leonhardt SD, Menzel F, Nehring V, Schmitt T (2016) Ecology and evolution of communication in social insects. Cell 164:12771287. https://doi.org/10.1016/j.cell.2016.01.035

Liebig J, Peeters C, Oldham NJ et al (2000) Are variations in cuticular hydrocarbons of queens and workers a reliable signal of fertility in the ant Harpegnathos saltator? Proc Natl Acad Sci USA 97:4124-4131. https://doi.org/10.1073/pnas.97.8.4124

Linksvayer TA (2007) Ant species differences determined by epistasis between brood and worker genomes. PLoS One 2:e994. https:// doi.org/10.1371/journal.pone.0000994

Linksvayer TA (2008) Queen-worker-brood coadaptation rather than conflict may drive colony resource allocation in the ant Temnothorax curvispinosus. Behav Ecol Sociobiol 62:647-657. https ://doi.org/10.1007/s00265-007-0489-9

Lopes JFS, Hughes WOH, Camargo RS, Forti LC (2005) Larval isolation and brood care in Acromyrmex leaf-cutting ants. Insectes Soc 52:333-338. https://doi.org/10.1007/s00040-005-0816-y

Maeder A, Freitag A, Cherix D (2005) Species and nestmate brood discrimination in the sibling wood ant species Formica paralugubris and Formica lugubris. Ann Zool Fennici 42:201-212. https://www.jstor.org/stable/23735908

Martin SJ, Drijfhout FP (2009a) A review of ant cuticular hydrocarbons. J Chem Ecol 35:1151-1161. https://doi.org/10.1007/s1088 6-009-9695-4

Martin SJ, Drijfhout FP (2009b) Nestmate and task cues are influenced and encoded differently within ant cuticular hydrocarbon profiles. J Chem Ecol 35:368-374. https://doi.org/10.1007/s1088 6-009-9612-X

Martin SJ, Helanterä H, Drijfhout FP (2008a) Colony-specific hydrocarbons identify nest mates in two species of Formica ant. J Chem Ecol 34:1072-1080. https://doi.org/10.1007/s1088 6-008-9482-7

Martin SJ, Helanterä H, Drijfhout FP (2008b) Evolution of species-specific cuticular hydrocarbon patterns in 
Formica ants. Biol J Linn Soc 95:131-140. https://doi.org/10.1 111/j.1095-8312.2008.01038.x

Martin SJ, Helanterä H, Kiss K et al (2009) Polygyny reduces rather than increases nestmate discrimination cue diversity in Formica exsecta ants. Insectes Soc 56:375-383. https://doi.org/10.1007/ s00040-009-0035-z

Martin SJ, Helanterä H, Drijfhout FP (2011) Is parasite pressure a driver of chemical cue diversity in ants? Proc R Soc B Biol Sci 278:496-503. https://doi.org/10.1098/rspb.2010.1047

Maynard Smith J, Harper D (2003) Animal signals. Oxford University Press, Oxford

McKenzie SK, Kronauer DJC (2018) The genomic architecture and molecular evolution of ant odorant receptors. Genome Res 28:1757-1765. https://doi.org/10.1101/gr.237123.118

McKenzie SK, Oxley PR, Kronauer DJC (2014) Comparative genomics and transcriptomics in ants provide new insights into the evolution and function of odorant binding and chemosensory proteins. BMC Genom 15:718. https://doi.org/10.1186/1471-2164-15-718

Meudec M (1978) Response to and transport of brood by workers of Tapinoma erraticum (Formicidae; Dolichoderinae) during nest disturbance. Behav Process 3:199-209. https://doi. org/10.1016/0376-6357(78)90013-X

Meunier JM, Delaplace L, Chapuisat M (2010) Reproductive conflicts and egg discrimination in a socially polymorphic ant. Behav Ecol Sociobiol 64:1655-1663. https://doi.org/10.1007/s0026 5-010-0979-z

Meunier JM, Delémont O, Lucas C (2011) Recognition in ants: social origin matters. PLoS One 6:e19347. https://doi.org/10.1371/ journal.pone.0019347

Mohammedi A, Crauser D, Paris A, Le Conte Y (1996) Effect of a brood pheromone on honeybee hypopharyngeal glands. C R Acad Sci III 319:769-772

Monnin T (1999) Dominance hierarchy and reproductive conflicts among subordinates in a monogynous queenless ant. Behav Ecol 10:323-332. https://doi.org/10.1093/beheco/10.3.323

Monnin T, Peeters C (1997) Cannibalism of subordinates' eggs in the monogynous queenless ant Dinoponera quadriceps. Naturwissenschaften 84:499-502. https://doi.org/10.1007/s001140050

Morel L, Vander Meer RK (1988) Do ant brood pheromones exist? Ann Entomol Soc Am 81:705-710. https://doi.org/10.1093/ aesa/81.5.705

Mori A, Le Moli F (1988) The role of different stimuli in eliciting cocoon care behaviour in Formica cunicularia ant-workers (Hymenoptera: Formicidae). Bolletino di Zool 55:93-98. https ://doi.org/10.1080/11250008809386605

Mori A, Zaccone A, Le Moli F (1992) Experience-independent attraction to host-species ant cocoons in the slave-maker Formica sanguinea Latr. (Hymenoptera Formicidae). Ethol Ecol Evol 4:85-89. https://doi.org/10.1080/03949370.1992.10721954

Mori A, d'Ettorre P, Le Moli F (1996) Selective acceptance of the brood of two formicine slave-making ants by host and nonhost related species. Insectes Soc 43:391-400. https://doi. org/10.1007/BF01258411

Muscedere ML, Willey TA, Traniello JFA (2009) Age and task efficiency in the ant Pheidole dentata: young minor workers are not specialist nurses. Anim Behav 77:911-918. https://doi. org/10.1016/j.anbehav.2008.12.018

Nakata K, Tsuji K (1996) The effect of colony size on conflict over male-production between gamergate and dominant workers in the ponerine ant Diacamma sp. Ethol Ecol Evol 8:147-156. https:// doi.org/10.1080/08927014.1996.9522925

Nehring V, Evison SEF, Santorelli LA et al (2011) Kin-informative recognition cues in ants. Proc R Soc B Biol Sci 278:1942-1948. https://doi.org/10.1098/rspb.2010.2295

Neupert S, Hornung M, Grenwille Millar J, Kleineidam CJ (2018) Learning distinct chemical labels of nestmates in ants. Front
Behav Neurosci 12:1-12. https://doi.org/10.3389/fnbeh .2018 .00191

Newey P (2011) Not one odour but two: a new model for nestmate recognition. J Theor Biol 270:7-12. https://doi.org/10.1016/j. jtbi.2010.10.029

Nonacs P, Carlin NF (1990) When can ants discriminate the sex of brood? A new aspect of queen-worker conflict. Proc Natl Acad Sci USA 87:9670-9673. https://doi.org/10.1073/pnas.87.24.9670

Ozaki M, Wada-Katsumata A (2010) Perception and oflcation of chemical compounds. In: Blomquist GJ, Bagnères A-G (eds) Insect hydrocarbons: biology, biochemistry and chemical ecology. Cambridge University Press, Cambridge, pp 210-221

Ozaki M, Ayako W-K, Kazuyo F et al (2005) Ant nestmate and nonnestmate discrimination by a chemosensory sensillum. Science 309:311-314. https://doi.org/10.1042/bj20101771

Pask GM, Slone JD, Millar JG et al (2017) Specialized odorant receptors in social insects that detect cuticular hydrocarbon cues and candidate pheromones. Nat Commun 8:297. https://doi. org/10.1038/s41467-017-00099-1

Passera L, Aron S (1996) Early sex discrimination and male brood elimination by workers of the Argentine ant. Proc R Soc B Biol Sci 263:1041-1046. https://doi.org/10.1098/rspb.1996.0153

Passera L, Aron S, Bach D (1995) Elimination of sexual brood in the Argentine ant Linepithema humile: queen effect and brood recognition. Entomol Exp Appl 75:203-212. https://doi. org/10.1111/j.1570-7458.1995.tb01928.x

Passera L, Aron S, Vargo EL, Keller L (2001) Queen control of sex ratio in fire ants. Science 293:1308-1310. https://doi. org/10.1126/science. 1062076

Paul B, Paul M, Annagiri S (2016) Opportunistic brood theft in the context of colony relocation in an Indian queenless ant. Sci Rep 6:1-10. https://doi.org/10.1038/srep36166

Peacock A, Smith I, Hall D, Baxter A (1954) Studies in pharaoh's ant, Monomorium pharaonis (L.). 8. Male production by parthenogenesis. Entomol Monogr Mag 90:154-158

Peeters C, Monnin T, Malosse C (1999) Cuticular hydrocarbons correlated with reproductive status in a queenless ant. Proc R Soc B Biol Sci 266:1323-1327. https://doi.org/10.1098/rspb.1999.0782

Pegnier M, Pokorny T, Heinze J et al (2019) Honesty of larval begging signals covaries with colony kin structure in Formica ants. Front Ecol Evol 7:398. https://doi.org/10.3389/fevo.2019.00398

Penick CA, Liebig J (2012) Regulation of queen development through worker aggression in a predatory ant. Behav Ecol 23:992-998. https://doi.org/10.1093/beheco/ars062

Penick CA, Liebig J (2017) A larval 'princess pheromone' identifies future ant queens based on their juvenile hormone content. Anim Behav 128:33-40. https://doi.org/10.1016/j.anbehav.2017.03.029

Penick CA, Tschinkel WR (2008) Thermoregulatory brood transport in the fire ant, Solenopsis invicta. Insectes Soc 55:176-182. https:// doi.org/10.1007/s00040-008-0987-4

Penick CA, Copple R, Mendez R, Smith A (2012) The role of anchortipped larval hairs in the organization of ant colonies. PLoS One 7:e41595. https://doi.org/10.1371/journal.pone.0041595

Penick CA, Ebie J, Moore D (2014) A non-destructive method for identifying the sex of ant larvae. Insectes Soc 61:51-55. https:// doi.org/10.1007/s00040-013-0323-5

Petralia RS, Vinson SB (1978) Feeding in the larvae of the imported fire ant, Solenopsis invicta: behavior and morphological adaptations. Ann Entomol Soc Am 71:643-648. https://doi. org/10.1093/aesa/71.4.643

Petralia RS, Vinson SB (1979a) Developmental morphology of larvae and eggs of the imported fire ant, Solenopsis invicta. Ann Entomol Soc Am 72:472-484. https://doi.org/10.1093/aesa/72.4.472

Petralia RS, Vinson SB (1979b) Comparative anatomy of the ventral region of ant larvae, and its relation to feeding behavior. Psyche 86:375-394 
Plateaux L (1960a) Adoptions experimental de larves entre des fourmis de genres différents: Leptothorax nylanderi (FÖRSTER) et Solenopsis fugax (LATREILLE). Insectes Soc 7:163-170. https ://doi.org/10.1007/BF02224077

Plateaux L (1960b) Adoptions experimental de larves entre des fourmis de genres différents: Myrmica laevinodis NYLANDER et Angergates atratulus SCHENCK. Insectes Soc 7:221-226

Plateaux L (1960c) Adoptions experimentales de larves entre des fourmis de genres differents: (III) Anergates atratulus SCHENCK et Solenopsis fugax LATREILLE-(IV) Leptothorax nylanderi FÖRSTER et Tetramorium caespitum L. Insectes Soc 7:345-348

Pollock G, Rissing SW (1989) Intraspecific brood raiding, territoriality, and slavery in ants. Am Nat 133:61-70. https://doi. org/10.1086/284901

Pulliainen U, Bos N, d'Ettorre P, Sundström L (2018) Caste-dependent brood retrieval by workers in the ant Formica exsecta. Anim Behav 140:151-159. https://doi.org/10.1016/j.anbeh av.2018.04.015

Pulliainen U, Helanterä H, Sundström L, Schultner E (2019) The possible role of ant larvae in the defence against social parasites. Proc R Soc B Biol Sci 286:20182867. https://doi.org/10.1098/ rspb.2018.2867

Punttila P (1996) Succession, forest fragmentation, and the distribution of wood ants. Oikos 75:291-298. https://doi. org/10.2307/3546252

Ratnieks FLW (1988) Reproductive harmony via mutual policing by workers in eusocial Hymenoptera. Am Nat 132:217-236. https ://doi.org/10.1086/284846

Ratnieks FLW (1991) The evolution of genetic odor-cue diversity in social Hymenoptera. Am Nat 137:202-226. https://doi. org/10.1086/285154

Ratnieks FLW, Keller L (1998) Queen control of egg fertilization in the honey bee. Behav Ecol Sociobiol 44:57-61. https://doi. org/10.1007/s002650050

Ratnieks FLW, Foster KR, Wenseleers T (2006) Conflict resolution in insect societies. Annu Rev Entomol 51:581-608. https://doi. org/10.1146/annurev.ento.51.110104.151003

Richard FJ, Poulsen M, Drijfhout FP et al (2007) Specificity in chemical profiles of workers, brood and mutualistic fungi in Atta, Acromyrmex, and Sericomyrmex fungus-growing ants. J Chem Ecol 33:2281-2292. https://doi.org/10.1007/s1088 6-007-9385-z

Robinson SW, Cherrett JM (1974) Laboratory investigations to evaluate the possible use of brood Pheromones of the leaf-cutting ant Atta cephalotes (L.) (Formicidae, Attini) as a component in an attractive bait. Bull Entomol Res 63:519-529. https://doi.org/10.1017/ S0007485300040992

Römer D, Roces F (2014) Nest enlargement in leaf-cutting ants: relocated brood and fungus trigger the excavation of new chambers. PLoS One 9:e97872. https://doi.org/10.1371/journal.pone.00978 72

Rosengren R, Cherix D (1981) The pupa-carrying test as a taxonomic tool in the Formica rufa group. In: Howse P, Clément J-L (eds) Biosystematics of social insects. Academic Press, London and New York, pp 263-281

Rosengren R, Chautems D, Cherix D et al (1994) Separation of two sympatric sibling species of Formica $\mathrm{L}$. ants by a behavioural test based on brood discrimination. Memorab Zool 48:237-249

Rosset H, Chapuisat M (2006) Sex allocation conflict in ants: when the queen rules. Curr Biol 16:328-331. https://doi.org/10.1016/j. cub.2005.12.036

Rüger MH, Fröba J, Foitzik S (2007) Larval cannibalism and workerinduced separation of larvae in Hypoponera ants: a case of conflict over caste determination? Insectes Soc 55:12-21. https://doi. org/10.1007/s00040-007-0965-2
Schmid-Hempel P (1995) Parasites and social insects. Apidologie 26:255-271. https://doi.org/10.1051/apido:19950307

Schneirla T (1971) The army ants—a study in social organization. Freeman, San Francisco

Schönrogge K, Barbero F, Casacci LP et al (2017) Acoustic communication within ant societies and its mimicry by mutualistic and socially parasitic myrmecophiles. Anim Behav 134:249-256. https://doi.org/10.1016/j.anbehav.2016.10.031

Schultner E, d'Ettorre P, Helanterä H (2013) Social conflict in ant larvae: egg cannibalism occurs mainly in males and larvae prefer alien eggs. Behav Ecol 24:1306-1311. https://doi.org/10.1093/ beheco/art067

Schultner E, Gardner A, Karhunen M, Helanterä H (2014) Ant larvae as players in social conflict: relatedness and individual identity mediate cannibalism intensity. Am Nat 184:E161-E174. https:// doi.org/10.1086/678459

Schultner E, Oettler J, Helanterä H (2017) The role of brood in eusocial Hymenoptera. Q Rev Biol 92:39-78. https://doi. org/10.1086/690840

Schumann R, Buschinger A (1991) Selective acceptance of alien host species pupae by slaves of the dulotic ant, Harpagoxenus sublaevis (Hymenoptera, Formicidae, Myrmicinae). Ethology 88:154-162. https://doi.org/10.1111/j.1439-0310.1991.tb00270.x

Seid MA, Junge E (2016) Social isolation and brain development in the ant Camponotus floridanus. Sci Nat 103:42. https://doi. org/10.1007/s00114-016-1364-1

Sendova-Franks AB, Scholes SR, Franks NR, Melhuish C (2004) Brood sorting by ants: two phases and differential diffusion. Anim Behav 68:1095-1106. https://doi.org/10.1016/j.anbeh av.2004.02.013

Shimoji H, Fujiki Y, Yamaoka R, Tsuji K (2012) Egg discrimination by workers in Diacamma sp. from Japan. Insectes Soc 59:201-206. https://doi.org/10.1007/s00040-011-0205-7

Signorotti L, Jaisson P, d'Ettorre P (2014) Larval memory affects adult nest-mate recognition in the ant Aphaenogaster senilis. Proc R Soc B Biol Sci 281:20132579. https://doi.org/10.1098/ rspb.2013.2579

Slone JD, Pask GM, Ferguson ST et al (2017) Functional characterization of odorant receptors in the ponerine ant, Harpegnathos saltator. Proc Natl Acad Sci 114:8586-8591. https://doi. org/10.1073/pnas.1704647114

Smith CR, Suarez AV (2010) The trophic ecology of castes in harvester ant colonies. Funct Ecol 24:122-130. https://doi.org/10.1 $111 / \mathrm{j} .1365-2435.2009 .01604 . \mathrm{x}$

Smith AA, Hölldobler B, Liebig J (2008a) Hydrocarbon signals explain the pattern of worker and egg policing in the ant Aphaenogaster cockerelli. J Chem Ecol 34:1275-1282. https://doi.org/10.1007/ s10886-008-9529-9

Smith CR, Anderson K, Tillberg CV et al (2008b) Caste determination in a polymorphic social insect: nutritional, social, and genetic factors. Am Nat 172:497-507. https://doi.org/10.1086/590961

Solazzo G, Moritz RFA, Settele J (2013) Choice behaviour of Myrmica rubra workers between ant larvae and larvae of their Phengaris (Maculinea) nausithous nest parasites. Insectes Soc 60:57-64. https://doi.org/10.1007/s00040-012-0265-3

Solis DR, Fox EGP, Kato LM et al (2010a) Morphological description of the immatures of the ant, Monomorium floricola. J Insect Sci 10:15. https://doi.org/10.1673/031.010.1501

Solis DR, Fox EGP, Rossi M, Bueno O (2010b) Description of the immatures of Linepithema humile Mayr (Hymenoptera: Formicidae). Biol Res 43:19-30. https://doi.org/10.4067/S0716-97602 010000100004

Solis DR, Nakano MA, Fox EGP et al (2011) Description of the immatures of the ant, Myrmelachista catharinae. J Insect Sci 11:24. https://doi.org/10.1673/031.011.0124 
Solis DR, Fox EGP, Ceccato M et al (2012a) On the morphology of the worker immatures of the leafcutter ant Atta sexdens linnaeus (Hymenoptera: Formicidae). Microsc Res Tech 75:1059-1065. https://doi.org/10.1002/jemt.22031

Solis DR, Fox EGP, Rossi M, Bueno O (2012b) Compared morphology of the immatures of males of two urban ant species of Camponotus. J Insect Sci 12:59. https://doi.org/10.1673/031.012.5901

Soroker V, Vienne C, Hefetz A (1995) Hydrocarbon dynamics within and between nestmates in Cataglyphis niger (Hymenoptera: Formicidae). J Chem Ecol 21:365-378. https://doi.org/10.1007/ BF02036724

Souza D, Della Lucia T, Errard C et al (2006) Behavioural and chemical studies of discrimination processes in the leaf-cutting ant Acromyrmex laticeps nigrosetosus (FOREL, 1908). Braz J Biol 66:863-871. https://doi.org/10.1590/S1519-69842006000500012

Stroeymeyt N, Brunner E, Heinze J (2007) "Selfish worker policing" controls reproduction in a Temnothorax ant. Behav Ecol Sociobiol 61:1449-1457. https://doi.org/10.1007/s00265-007-0377-3

Sturgis SJ, Gordon DM (2012) Nestmate recognition in ants (Hymenoptera: Formicidae): a review. Myrmecol News 16:101-110

Sundström L (1997) Queen acceptance and nestmate recognition in monogyne and polygyne colonies of the ant Formica truncorum. Anim Behav 53:499-510. https://doi.org/10.1006/ anbe. 1996.0300

Sundström L, Chapuisat M, Keller L (1996) Conditional manipulation of sex ratios by ant workers: a test of kin selection theory. Science 274:993-994. https://doi.org/10.1126/science.274.5289.993

Swan DC, Hare JF (2012) Larval recognition by Temnothorax longispinosus and T. ambiguus hosts of the slave-making ant Protomognathus americanus revisited: colony-level referent ensures conspecific preference. Insectes Soc 59:511-517. https://doi. org/10.1007/s00040-012-0245-7

Tannure-Nascimento IC, Nascimento FS, Dantas JO, Zucchi R (2009) Decision rules for egg recognition are related to functional roles and chemical cues in the queenless ant Dinoponera quadriceps. Naturwissenschaften 96:857-861. https://doi.org/10.1007/s0011 4-009-0535-8

Tay WT, Crozier RH (2000) Nestmate interactions and egg-laying behaviour in the queenless ponerine ant Rhytidoponera sp. 12. Insectes Soc 47:133-140. https://doi.org/10.1007/PL00001691

Teseo S, Kronauer DJC, Jaisson P, Châline N (2013) Enforcement of reproductive synchrony via policing in a clonal ant. Curr Biol 23:328-332. https://doi.org/10.1016/j.cub.2013.01.011

Teseo S, Lecoutey E, Kronauer DJC et al (2014) Genetic distance and age affect the cuticular chemical profiles of the clonal ant Cerapachys biroi. J Chem Ecol 40:429-438. https://doi.org/10.1007/ s10886-014-0428-y

Thomas JA, Elmes GW, Wardlaw JC (1998) Polymorphic growth in larvae of the butterfly Maculinea rebeli a social parasite of Myrmica ant colonies. Proc R Soc B Biol Sci 265:1895-1901. https ://doi.org/10.1098/rspb.1998.0517

Thomas JA, Elmes GW, Sielezniew M et al (2013) Mimetic host shifts in an endangered social parasite of ants. Proc R Soc B Biol Sci 280:20122336. https://doi.org/10.1098/rspb.2012.2336

Tinbergen N (1963) On the aims and methods of ethology. Z Tierpsychol 20:410-433

Trible W, Kronauer DJC (2017) Caste development and evolution in ants: it's all about size. J Exp Biol 220:53-62. https://doi. org/10.1242/jeb.145292

Trible W, Olivos-Cisneros L, McKenzie SK et al (2017) orco mutagenesis causes loss of antennal lobe glomeruli and impaired social behavior in ants. Cell 170:727-735.e10. https://doi.org/10.1016/j. cell.2017.07.001

Trivers RL, Hare H (1976) Haplodiploidy and the evolution of the social insects. Science 191:249-263. https://doi.org/10.1126/ science. 1108197
Tschinkel WR (2006) The fire ants. Harvard University Press, Cambridge

Tsutsui ND (2013) Dissecting ant recognition systems in the age of genomics. Biol Lett 9:20130416. https://doi.org/10.1098/ rsbl.2013.0416

Ulrich Y, Burns D, Libbrecht R, Kronauer DJC (2016) Ant larvae regulate worker foraging behavior and ovarian activity in a dosedependent manner. Behav Ecol Sociobiol 70:1011-1018. https:// doi.org/10.1007/s00265-015-2046-2

Van Oystaeyen A, Oliveira RC, Holman L et al (2014) Conserved class of queen pheromones stops social insect workers from reproducing. Science 343:287-290. https://doi.org/10.1126/science.12448 99

van Wilgenburg E, Symonds MRE, Elgar MA (2011) Evolution of cuticular hydrocarbon diversity in ants. J Evol Biol 24:11881198. https://doi.org/10.1111/j.1420-9101.2011.02248.x

van Zweden JS, d'Ettorre P (2010) Nestmate recognition in social insects and the role of hydrocarbons. In: Blomquist GJ, Bagneres A (eds) Insect hydrocarbons: biology, biochemistry and chemical ecology

van Zweden JS, Fürst M, Heinze J, d'Ettorre P (2007) Specialization in policing behavior among workers in the ant Pachycondyla inversa. Proc R Soc B Biol Sci 274:1421-1428. https://doi. org/10.1098/rspb.2007.0113

van Zweden JS, Dreier S, d'Ettorre P (2009a) Disentangling environmental and heritable nestmate recognition cues in a carpenter ant. J Insect Physiol 55:158-163. https://doi.org/10.1016/j.jinsp hys.2008.11.001

van Zweden JS, Heinze J, Boomsma JJ, d'Ettorre P (2009b) Ant queen egg-marking signals: matching deceptive laboratory simplicity with natural complexity. PLoS One 4:e4718. https://doi. org/10.1371/journal.pone.0004718

van Zweden JS, Brask J, Christensen J et al (2010) Blending of heritable recognition cues among ant nestmates creates distinct colony gestalt odours but prevents within-colony nepotism. J Evol Biol 23:1498-1508. https://doi.org/10.1111/j.1420-9101.2010.02020 .x

Vander Meer RK (1983) Semiochemicals and the red imported fire ant (Solenopsis invicta Buren) (Hymenoptera: Formicidae). Florida Entomol 66:139-161

Vander Meer RK, Alonso LE (1998) Pheromone directed behavior in ants. In: Vander Meer R, Breed M, Winston M, Espelie K (eds) Pheromone communication in social insects. Westview Press, Boulder, pp 159-192

Vander Meer RK, Morel L (1988) Brood pheromones in ants. In: Trager J (ed) Advances in myrmecology. E.J. Brill, New York, pp 491-513

Vander Meer RK, Breed M, Espelie K (eds) (1998) Pheromone communication in social insects. Westview Press, Boulder

Vargo EL, Fletcher DJC (1986) Evidence of pheromonal queen control over the production of male and female sexuals in the fire ant, Solenopsis invicta. J Comp Physiol A 159:741-749. https://doi. org/10.1007/BF00603727

Viana AMM, Frézard A, Malosse C et al (2001) Colonial recognition of fungus in the fungus-growing ant Acromyrmex subterraneus subterraneus (Hymenoptera: Formicidae). Chemoecology 11:29-36. https://doi.org/10.1007/PL00001829

Vienne C, Errard C, Lenoir A (2010) Influence of the queen on worker behaviour and queen recognition behaviour in ants. Ethology 104:431-446. https://doi.org/10.1111/j.1439-0310.1998.tb000 81.x

Villalta I, Angulo E, Devers S et al (2015) Regulation of worker egg laying by larvae in a fission-performing ant. Anim Behav 106:149-156. https://doi.org/10.1016/j.anbehav.2015.05.021 
Villalta I, Amor F, Cerdá X, Boulay R (2016) Social coercion of larval development in an ant species. Sci Nat 103:18. https://doi. org/10.1007/s00114-016-1341-8

Vowles DM (1955) The foraging of ants. Br J Anim Behav 3:1-13. https://doi.org/10.1016/S0950-5601(55)80069-X

Wada-Katsumata A, Yamaoka R, Aonuma H (2011) Social interactions influence dopamine and octopamine homeostasis in the brain of the ant Formica japonica. J Exp Biol 214:1707-1713. https://doi. org/10.1242/jeb.051565

Wagner D, Brown MJF, Broun P et al (1998) Task-related differences in the cuticular hydrocarbon composition of harvester ants, Pogonomyrmex barbatus. J Chem Ecol 24:2021-2037. https:// doi.org/10.1023/A:1020781508889

Wagner D, Brown MJF, Broun P et al (2001) Task-related environment alters the cuticular hydrocarbon composition of harvester ants. J Chem Ecol 27:1805-1819. https://doi.org/10.1023/A:10104 08725464

Waldman B (1987) Mechanisms of kin recognition. J Theor Biol 128:159-185. https://doi.org/10.1016/S0022-5193(87)80167-4

Walsh J, Tschinkel WR (1974) Brood recognition by contact pheromone in the red imported fire ant, Solenopsis invicta. Anim Behav 22:695-704. https://doi.org/10.1016/S0003-3472(74)80020-5

Walsh JT, Signorotti L, Linksvayer TA, d'Ettorre P (2018a) Phenotypic correlation between queen and worker brood care supports the role of maternal care in the evolution of eusociality. Ecol Evol 8:10409-10415. https://doi.org/10.1002/ece3.4475

Walsh JT, Warner MR, Kase A et al (2018b) Ant nurse workers exhibit behavioural and transcriptomic signatures of specialization on larval stage. Anim Behav 141:161-169. https://doi.org/10.1016/j. anbehav.2018.05.015

Wang Q, Goodger JQDD, Woodrow IE, Elgar MA (2016) Locationspecific cuticular hydrocarbon signals in a social insect. Proc R Soc B Biol Sci 283:20160310. https://doi.org/10.1098/ rspb.2016.0310

Wang Y, Zuber R, Laudahn A et al (2017) Cuticular body hairs mediate clumping of small Camponotus floridanus larvae. Arthropod Struct Dev 46:108-115. https://doi.org/10.1016/j. asd.2016.12.003

Warner MR, Kovaka K, Linksvayer TA (2016) Late-instar ant worker larvae play a prominent role in colony-level caste regulation. Insectes Soc 63:1-9. https://doi.org/10.1007/s00040-016-0501-3
Warner MR, Mikheyev A, Linksvayer TA (2019) Transcriptomic basis and evolution of the ant nurse-larval social interactome. PLoS Genet 15:e1008156. https://doi.org/10.1371/journal.pgen.10081 56

Watkins JF, Cole T (1966) The attraction of army ant workers to secretions of their queens. Texan J Sci 18:254-265

Wenseleers T, Ratnieks FLW (2006) Comparative analysis of worker reproduction and policing in eusocial hymenoptera supports relatedness theory. Am Nat 168:E163-E179. https://doi. org/10.1086/508619

Wheeler W (1910) Ants: their structure, development and behavior. Columbia University Press, New York

Wheeler W (1918) A study of some ant larvae, with a consideration of the origin and meaning of the social habit among insects. Proc Am Philos Soc 57:293-343

Wheeler GC, Wheeler J (1953) The ant larvae of the subfamily Formicinae. Ann Entomol Soc Am 46:126-171. https://doi.org/10.1093/ aesa/46.1.126

Wheeler GC, Wheeler J (1976) Ant larvae: review and synthesis. Mem Entomol Soc Washingt 7:1-108

Wheeler GC, Wheeler J (1986) Ten-year supplement to "Ant larvae: review and synthesis". Proc Entomol Soc Washingt 88:684-702

Will S, Delabie JHC, Heinze J et al (2012) Cuticular lipid profiles of fertile and non-fertile Cardiocondyla ant queens. J Insect Physiol 58:1245-1249. https://doi.org/10.1016/j.jinsphys.2012.06.009

Wilson EO (1971) The insect societies. Harvard University Press, Cambridge

Witte V, Lehmann L, Lustig A, Maschwitz U (2009) Polyrhachis lama, a parasitic ant with an exceptional mode of social integration. Insectes Soc 56:301-307. https://doi.org/10.1007/s0004 0-009-0024-2

Yan H, Opachaloemphan C, Mancini G et al (2017) An engineered orco mutation produces aberrant social behavior and defective neural development in ants. Cell 170:736-747.e9. https://doi. org/10.1016/j.cell.2017.06.051

Zimmerli EJ, Mori A (1993) The role of an attractive brood pheromone in the obligatory, slavemaking ant, Poylergus breviceps (Hymenoptera: Formicidae). J Insect Behav 6:761-770. https:// doi.org/10.1007/BF01201675 